Reprod. Nutr. Dévelop., 1987, 27 (5), 865-896.

\title{
Mammalian oocyte maturation
}

\author{
C. THIBAULT, D. SZÖLLÖSI, Micheline GÉRARD
}

Université de Paris VI et

I.N.R.A., 78350 Jouy-en-Josas, France.

Although the spontaneous resumption of meiosis has been observed in mammalian oocyte freed from follicular cells by Pincus more than fifty years ago it is only during the past two decades that factors involved in the maintenance of meiotic arrest have been recognized. However, their nature remains controversial as well as the causes of their inactivation after the preovulatory gonadotropin surge. Our experimental data and cytological observations enable us to suggest a synthesis integrating most of the contradictory data of the literature.

Moroever as indicated by Chang's experiments, as early as 1955, a final cytoplasmic maturation must run parallel to the nuclear maturation. We discovered in 1973, that granulosa cells are involved and during the last decade it has been shown that they modulate oocyte protein synthesis mainly but not exclusively through the nature and ratio of the steroids secreted. The indisputable proof of their role has been shown by birth of lambs after co-culture of granulosa and cumulus-oocyte complexes during in vitro oocyte maturation.

\section{I. - Nuclear maturation}

\section{A. - Meiotic competence.}

The growing oocyte becomes progressively capable of resuming meiosis and what is called " meiotic competence " only appears when the oocyte is about $80 \%$ of the size of the fully developed oocyte. In vivo this stage occurs around the period of antrum formation (mouse, Wassarman and Josefowicz, 1978 ; pig, Motlik, Crozet and Fulka, 1984 ; cattle, Motlik and Fulka, 1986). In vitro studies have shown that specialized membrane contacts with follicular cells are necessary to oocyte growth : growth is only maintained when oocytes are cultured encompassed by follicular cells but not on follicular cell monolayer, unless removal of the zona allows coupling (Buccione et al., 1987). FSH or estradiol does not seem beneficial (mouse, Eppig, 1977, 1979 ; Bachvarova et al., 1980). The favorable effect of these hormones on the percentage of competent oocytes in young hypophysectomized rats (Bar-Ami and Tsafriri, 1981) is probably related to the favorable effect of these hormones on the whole ovary and 
particularly on the follicular cells rather than to a specific action on the oocytes. Cocultured in contact with fibroblasts, oocytes do not grow but they survive (Canipari et al., 1984). When oocytes reach the critical size during culture, they are able to resume meiosis spontaneously. However, it is interesting to note that after 2 to 10 days of culture on fibroblast monolayer middle-size oocytes also resume meiosis spontaneously (Canipari et al., 1984) showing that the acquisition of meiotic competence depends on a genetical program developed by the oocyte itself but probably initiated by follicular cells at the beginning of follicle and oocyte growth. However, we must be reminded that oocytes may remain without any growth during many decades in long living mammals inside primordial follicles. That means that follicular cells at least as conveyors of ovarian factors first inhibit oocyte growth. On the contrary, when, for unknown reasons, follicle cells begin to divide, they stimulate oocyte growth and finally as the growing oocyte becomes " competent ", they have a direct inhibitory activity on meiosis resumption.

\section{B. - Meiosis resumption.}

\section{1. - Inhibitory factors.}

\section{1.-1. Inhibitory factors prevent meiosis resumption of " competent oocyte".}

In vivo competent oocytes do not resume meiosis before LH surge. However, when competent oocytes with or without cumulus cells are cultured outside their follicles they immediately resume meiosis spontaneously whatever the mammalian species (see Thibault, 1977).

This observation clearly indicates that follicular cells in antral follicles are responsible for meiotic arrest. More precisely inhibition come from granulosa cells as shown in one of our previous experiments : when cumulus-oocyte complexes were grafted in vitro on the granulosa of alien immature follicles meiosis did not resume ; on the contrary, theca cells are unable to maintain meiotic arrest (Foote and Thibault, 1969). These conclusions were followed by numerous attempts to isolate the inhibitor and to determine its chemical nature.

For the time being, at least three inhibitors have been described : the CAMP, the OMI (oocyte meiosis inhibitor) of Channing and Tsafriri, the purine nucleosides of Downs and Eppig. As more and more pro-hormones, hormones (and their mRNAs, Einspanier et al., 1986) are discovered in the ovary some may be candidates as recently mentioned for the SRIF (pig, Mori et al., 1985) and for the anti-mullerian hormone (AMH) (rat, Takahashi et al., 1986). However, with a more purified AMH preparation Tsafriri (personnal communication) has been unable to inhibit rat meiosis resumption. Thus many conclusions are open to criticism and many results are difficult to repeat because the conditions of the biological material are not sufficiently well-defined either at the beginning or the end of the experiment, or both. We wish to mention :

a) the instability of the percentage of meiosis resumption (MR) in control oocytes ; according to our experience with rabbit, cow, pig and monkey oocytes, 
only those from preovulatory follicles are able to resume meiosis up to metaphase If at a rate close to $100 \%$ and following a schedule identical to that observed in vivo. These are theoretically the only oocytes suitable for the study of inhibitors ;

b) the cytological quality of the granulosa and/or corona cells is rarely studied although it is well known that meiosis may resume in atretic follicles leading to a misinterpretation of the inhibitory effect of the substance studied. Atresia may occur in vitro very rapidly if medium-size or large follicles are stimulated by gonadotropins unless a high rate of metabolic exchange is provided. In our hands only perifusion technique (Ménézo et al., 1976) has been able to maintain such follicles in healthy condition for $24 \mathrm{~h}$ or more (Ménézo et al., 1976 ; Gérard et al., 1979). Moroever pycnosis is always observed when cumulus cells are cultured in serum free medium. This is an unfavorable situation when studying cooperation of cumulus cells with the maturation of oocytes ;

c) a rough observation of the nucleus (GV) or of its disapearance (GVBD) is insufficient for determining the cytological effect of the meiosis inhibitors studied as will be shown in the following pages.

\section{1-2. Some structural features of "competent-oocytes" and changes related to meiosis resumption.}

\section{1-2-1. General features.}

The mature oocyte is one of the largest cells in the body of mammals and represents a highly "specialized ", that is, differentiated cell. During the growth period all types of RNAs are actively synthesized and proteins lactine, tubuline, calmoduline, zona proteins, $\mathrm{LDH}, .$. ) accumulate (Moore and Lintern-Moore, 1978 ; Kaplan et al., 1982 ; Bachvarova et al., 1985). After the growth period a low rate of RNA synthesis is maintained, even if nucleolus compaction indicates that rRNA transcription is impaired. RNAs labelled during growth are present in the cytoplasm of ovulated oocytes (Fourcroy, 1982 ; Piko, 1982). At ovulation the majority of the ribosomes $(75 \%)$ are not engaged in protein synthesis : they are apparently stored in view of embryonic development (Bachvarova and De Leon, 1977).

As many developmental events, a particular phase of oogenesis such as meiotic maturation, the topic considered here, can not be arbitrarily isolated from the process in its entirety. It must also be considered that this cell established privileged spatial, functional and structural relationship with follicular cells and in a narrower sense with the cumulus cells, throughout its long development even in its last steps.

The ovarian oocytes of eutherian mammals recovered from large antral follicles, whose cytoplasmic diameter ranges between 60 and $150 \mu \mathrm{m}$, are composed of two compartments, the nucleus called, germinal vesicle (GV) and the cytoplasm. The plasma membrane is of the same structure, dimensions and composition as plasma membranes in general and is thrown into regularly spaced microvilli over the entire oocyte surface. An acellular glycoprotein glycan layer, the zona pellucida, synthesized by the oocyte at the beginning of its growth (Bleil 
and Wassarman, 1980), surrounds it in every case. A multiple layered cell mass of similar, cuboidal (orthogonal) cells, the cumulus oophorus, encompassed the oocyte. Those which appose against the zona directly called corona radiata are connected with the oocyte by one or few cytoplasmatic foot processes across the zona. The foot processes terminated in a bulbous button either attach to the

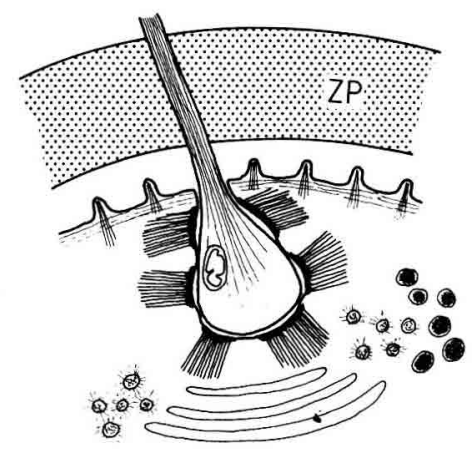

(A)

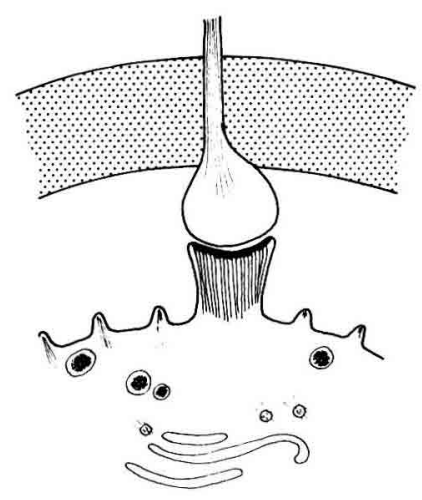

(C)

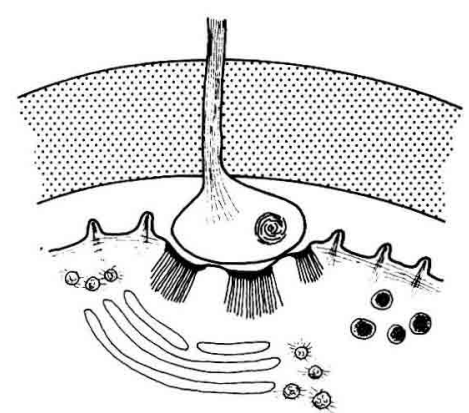

(B)

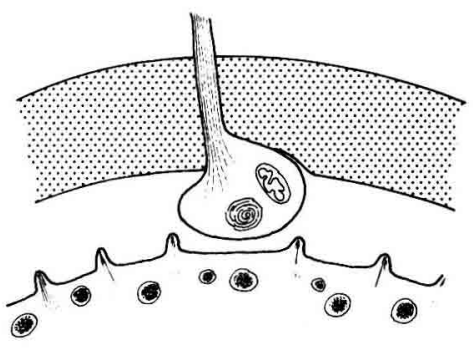

(D)

FIG. 1. - A schematic representation of the evolution of the corona cell - oocyte junctional complexes during oocyte maturation in some mammals, in which the foot processes indent deeply the oocyte plasma membrane $(A)$ in oocytes recovered from preovulatory follicles. The electron dense plaques of the intermediate junction type are alternating with small gap junctions. Filaments of the intermediate filament dimensions associate with the former. Golgi complexes are located in the proximity of the indentations ; cortical granules are in clusters near the plasma membrane. The oocyte surface is richly covered with microvilli whose core is occupied by actin filaments. Within 5-7 hrs. of culture with gonadotropins the foot processes are partially withdrawn and the "button » - like corona cell termini are in part exteriorized but both types of junctional complexes are retained $(B)$. The strength of the junctional complexes is so great that oocyte is deformed creating temporary protuberances into the perivitelline space by the retracting foot processes. The intermediate junctions are the dominant junction type (C). Simultaneously with GVBD the junctional complexes disappear and the oocyte regains it's spherical shape (D). 
RODENT OOCYTES
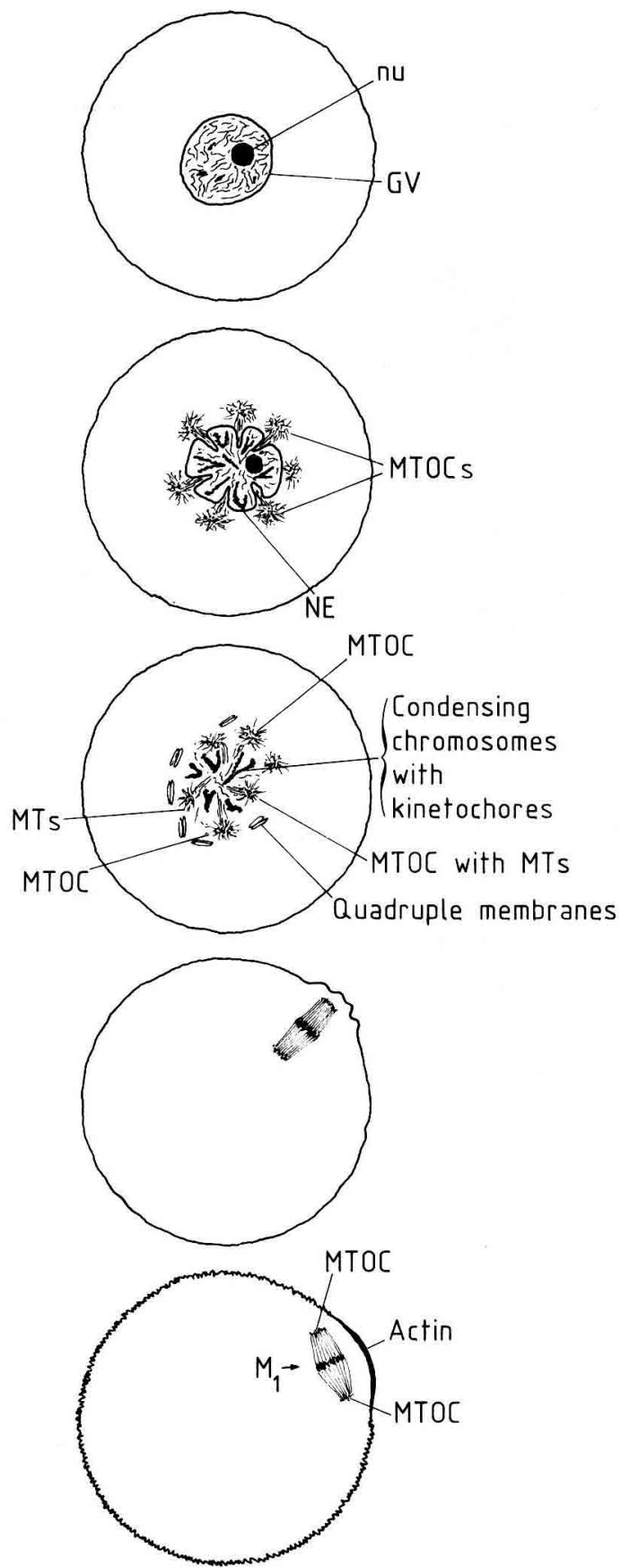

RUMINANT OOCYTES

869
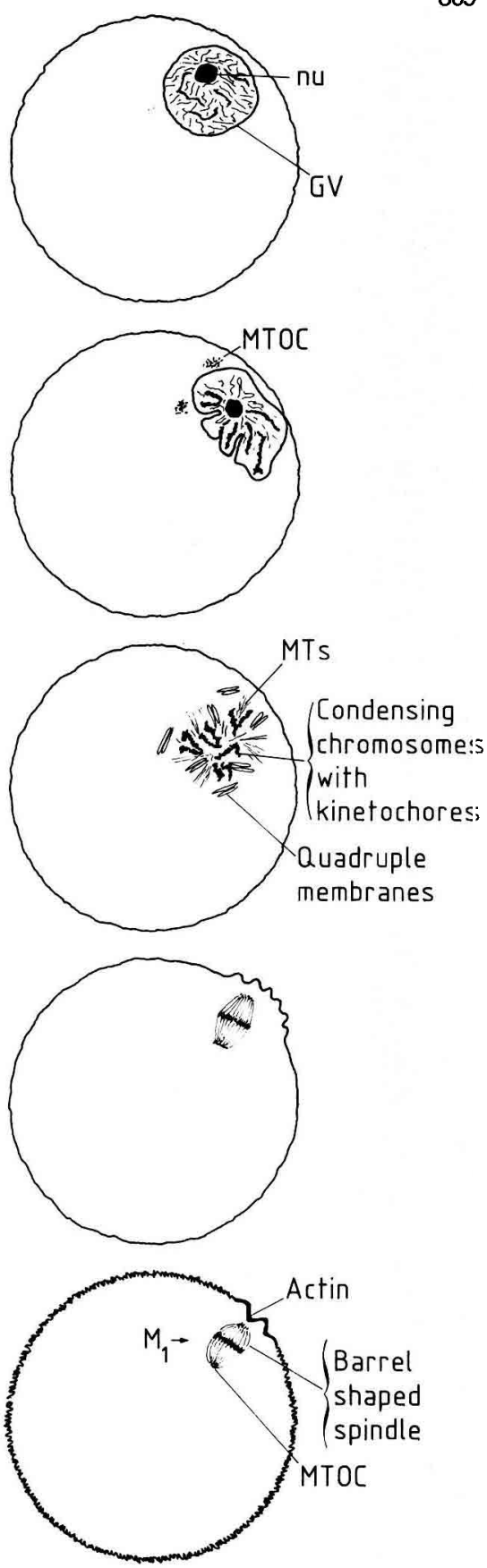

FIG. 2. - A schematic representation of GVBD in rodent and ruminant oocytes. Attention is drawn particularly to the central and peripheral location of the GV in the two respective groups and to the paratangential versus radial orientation of the meiotic spindle. MTOCs composed of distinct aggregations of electron dense filamentous material, which is evident in rodent oocytes, remains much more vague in ruminant oocytes. 
oocyte plasmalemma superficially (mouse, hamster, rat) or indent it deeply (rabbit, cow, sheep). Along the apposing membranes, junctional complexes of the intermediate type (zonula adherens) form incorporating spatially one to several small gap junctions (Anderson and Albertini, 1976; Anderson, 1977 ; Gilula et al., 1978 ; Szöllösi, 1978 ; Szöllösi et al., 1978). Thin filaments of the intermediate filament dimensions (\#10 nm) associate with the electron dense structural layer, representing most likely firm attachment between the heterologous cells (fig. 1).

Between the adjacent cumulus cell bodies and their narrow foot processes gap junctions of much larger dimensions form. In contrast to the cell junction between corona cells and oocyte, there are no intermediate type junctions between the cell bodies.

After LH surge the cells actively elongate, forming very long cell processes of larger diameter. Within intermediate and thin filaments, microtubules, few mitochondria and other cell organelles are found. Before the foot processes within the zona are either withdrown or destroyed, junction changes occur and they will be described below. The area of junctional complexes between both corona cells and cumulus and granulosa cells decrease when maturation is initiated (Larsen et al., 1986).

\section{1-2-2. Germinal vesicle, chromosome condensation, nuclear envelope breakdown.}

The germinal vesicle is located in the center of the oocyte in the mouse, the " standard mammal ». But in most other mammals, GV migrates gradually to the periphery corresponding to the gradual growth of the oocyte. The GV is spherical and possesses either a single or more rarely double nucleoli. In the GV of some mammals chromatin masses condense along the nuclear envelope (NE) projecting towards the nucleolus. A distinct perinuclear chromatine crown is routinely formed in pig (Daguet, 1980 ; Gérard et al., 1979) and in human oocytes (Tesarik et al., 1984) through most of the antral phase. In truly preovulatory oocytes but prior to LH surge the GV flattens against the plasma membrane. No physiological role can be assigned to this intriguing new membrane relationship in oocyte maturation (fig. 2).

FIG. 3. - Circular bivalent chromosome stage in sheep oocyte after 7 hrs. of culture with gonadotropins. The NE is deeply folded around the radially oriented chromosomes. Inset : detail of the NE demonstrates that it is still intact, that pores are absent and that the nucleoplasmic leaflet (facing each other) is more electron dense than the outer leaflet. The difference in density of the membranes is probably due to the existence of lamins still at this tage. $\times 7,200:$ Inset : $\times$ 45,000

FIG. 4. - Metaphase // of a porcine oocyte recovered from a large follicle of an estrous sow. The spindle is radially oriented. One spindle pole is close to an undulatory portion of the plasma membrane. Adjacent to it is a filament rich area embedding the entire spindle including the pole and occupying the space up to the plasma membrane. $\times 22,500$. 
The rupture of the nuclear envelope (GVBD) occurs whatever the position of the GV, to a thus far unidentified molecular signal referred to as MPF (meiotic promoting factor). The MPF is probably equivalent to a more general « mitotic factor " identified in somatic cell hybridization work (Sunkara et al., 1982). A more generally valid term will remove a mistic aura from a factor reputedly exclusively found in mature female germ cells.

GVBD was studied in detail only in the mouse (Calarco et al., 1972 ; Calarco, 1972) and in the cow (Kruip et al., 1983 ; Hyttel et al., 1986) oocytes and in lesser detail in the rabbit (Szöllösi, 1975) and sheep oocytes (unpublished observations).

The common features found in all are the deformation of the GV by indentations ending in chromosome condensation, arranged more or less radially but in the proximity of and in contact with the NE (fig. 3). It is referred to as the circular bivalent stage. The NE is still continuous, however. In light microscopic studies, GVBD may have wrongly and prematurely assumed at this stage. The pore complexes, very frequent along the NE of the GV in earlier stages, are totally absent (Calarco et al., 1972 ; Szöllösi et al., 1972a). No sign of any kind, nor interruptions of the envelope continuity mark their previous location.

Simultaneously with these changes, microtubule organizing centers (MTOCs, see 1-2-3) with associated microtubules (MTs) surround the mouse GV. The MT bundles are preferentially orientated along the cytoplasmic channels delineated by NE folds. Some tubules oriente towards the cytoplasm forming " mini-asters " (Szöllösi et al., 1972b ; Schatten et al., 1986a ; Maro et al., 1986). The NE is still nearly continous showing at best tiny breaks, large enough for the passage of a single or a small bundle of MTs.

During chromosome condensation, but preceding NE rupture, the kinetochores make their appearance. At first no MTs associate with them while several polymerize quickly as GVBD becomes more extensive (Calarco, 1972 ; Calarco et al., 1972 ; Szöllösi et al., 1972a). The condensed chromosomes lose their NE association and kinetochore microtubules form bundles, originally lacking a common axis between chromosomes.

Then the kinetochore MT bundles and the newly developing " pole to pole " MTs running parallel build the first meiotic spindle (Calarco, 1972). Possibly the precocious development of the multiple MTOCs and MTs surrounding the entire $\mathrm{GV}$ in the mouse is related to the central location of the GV. At GVBD, the whole newly formed spindle moves peripherally. The movement of the entire spindle in the mouse depend on the microfilament system, mainly composed of actin since it can be abolished by cytochalazin B (Longo and Chen, 1985). These events take

FIG. 5. - A) Mouse oocyte : a longitudinal section of a paratangentially oriented second meiotic spindle. The spindle is barrel-shaped and the microtubules composing it project to the right to a partially sectioned MTOC. From reconstruction of a number of parallel sections the MTOCs appear to be constituted on either pole of a slightly curved electron dense plaque. $\times 7,500$.

B) An MTOC from this series of sections at higher magnification is composed of electron dense thin filaments forming a felt-like mass and many small vesicles of different diameters. Small Golgi units are invariably located in the proximity of the MTOCs. Few microtubules penetrate the cytoplasm but most of them project towards the chromosomes and the bulk of the spindle. In the vicinity of the MTOC flat smooth endoplasmic reticulum vesicles are abundant. $\times 25,000$. 
place more slowly in pig, cow and sheep oocytes and can be analyzed more easily. In these oocytes with an already peripheral GV, micro-tubules do not appear around it and no MTOCs are recognized prior to GVBD. MTs polymerize in the intranuclear and interchromosomal spaces simultaneously with a clear cut GVBD (rabbit, Szöllösi, 1975 ; cattle, Hyttel et al., 1986). The inner leaflet of the NE is of slightly higher electron density, probably corresponding to the presence of nuclear lamins (Rime et al., 1987b ; Maul and Schatten, 1986 ; Maro et al., 1986).

The formed spindle orients originally radially towards the oocyte plasma membrane. At first a spindle pole-membrane association occurs, definable as a region of the plasma membrane with irregular folds and protrusions. In mouse oocytes the spindle takes up a paratangential orientation (Okada et al., 1986). The smooth, actin-associated, specialized membrane dome lacking microvilli appears only subsequent to spindle rotation. The cortical granules diminish locally first in the region where the spindle pole approaches by lateral movement and by their partial premature exocytosis.

This paratangential meiotic spindle orientation is particular to rodent oocytes (fig. 4a); in pig, cow, sheep, rabbit and human oocytes the spindle orientation remains radial (fig. 5). Correspondingly, the oocyte plasma membrane remains similar to the folded initial stage, demonstrating peculiar protrusions described for the hamster oocyte (Okada et al., 1986) while the large smooth dome (cone) underlain with actin never forms. The $\mathrm{M}$ I spindle forms a wider barrel-shaped structure than the M II spindle.

\section{1-2-3. Spindle formation and other cytoskeletal components.}

Even if the collective term cytoskeleton, implies a uniformity of the cytological constituants referred to in fact, the cytoskeleton is represented by different molecular assemblies of great complexity, diversity and interactions at various levels.

Detailed informations on the cytoskeleton in mammalian oocyte is just becoming available pertaining primarily to the distribution of actin, tubulin and to the MTOCs, while other components belonging to be keratin family are just emerging. Much of the information was collected on mouse oocytes.

One of the most unexpected modifications found in the mature oocyte is the change of the centrosome structure, referred to as the microtubule organizing center (MTOC) (fig. 4b). The centrioles are absent from this organelle retaining only the " pericentriolar material " as the organizer of the needed MTs either within the spindle apparatus or within the multiple cytoplasmic foci of microtubules (Szöllösi et al., 1972b). In ongonia and growing oocytes centrioles are present (Szöllösi et al., 1972a, b ; Anderson, 1972) but whether they are still functioning in their usual manner is not known. By immunocytochemical techniques a light background staining, most likely due to the soluble tubulin is found within the preovulatory oocyte. Multiple microtubule foci, scattered around the GV as small asters, appear as the nucleus is breaking down (mouse, Rime et al., 1987a, b). In sheep oocytes originating from small antral follicles there is also a 
wide distribution of tubulin through the entire cytoplasm; In the cortex microtubule bundles are not present in a localized manner.

Microtubule associated protein (MAP-1) is detected exclusively within the nucleoplasm and is sharply delimited at the NE level. The nucleolus also stains. When GVBD occurs microtubule foci stain with both anti-tubulin and anti-MAP 1 antibodies (JA 2). The metaphase I and metaphase II spindles stain with both antibodies which seem superimposable.

The localization of actin and myosin was studied on frozen sections in rat, mouse and sheep oocytes. In submature rat oocytes $(80-120 \mu \mathrm{m})$ actin is localized by fluorescent anti-actin antibodies beneath the entire surface (Amsterdam et al., 1976). A slight staining is already perceptible in growing oocytes $(30-40 \mu \mathrm{m})$. In ovulated rat oocytes and in zygotes a 3-5 $\mu \mathrm{m}$ fluorescent band was labelled by NBD-phallacidine, localizing specifically F-actin (Battaglia and Gaddum-Rosse, 1986). In sheep oocytes from small antral follicles F-actin is also uniformely localized in a narrow cortical band while anti-actin antibodies gave also a uniform nuclear staining (Le Guen, pers. comm.).

These results contrast directly with those obtained by several groups of investigators in ovulated and fertilized mouse eggs (Maro et al., 1986 ; Longo et Chen, 1985 ; Webb et al., 1986). In mouse there is a focal distribution at the site of polar body abstriction and sperm entry, in the region of both pronuclei and also around polar body II nucleus.

Other components of the cytoskeleton have been also actively studied. The presence of cytokeratin has been detected with specific antibodies in sheep oocytes removed from small antral follicles. On unfixed permeabilized oocytes a dense fibrous network, composed of fibers of different diameters could be demonstrated. In contrast when oocytes were fixed a spotty staining was visible throughout the oocytes ; in the cortex a uniformely distributed row of spots may correspond to the attachement and indentation sites of the corona foot processes shown in electron microscopy which region is rich in filaments of an intermediate diameter (Le Guen, pers. comm.).

Nuclear lamins $A, B$ and $C$, was recently identified in mouse and rat ovarian oocytes. Anti-lamins antibodies or lamin reacting sera of scleroderma patients evidenced a continous band lining the inner nuclear surface. At early GVBD stained fragments of the nuclear envelope are located in the area of the ruptured nucleus (Schatten et al., 1985b ; Maul and Schatten, 1986 ; Rime et al., 1987). Schatten et al. suggest that lamins $A-C$ and $B$ are integrated into the nuclear envelope when chromatin is attached to it, as is it the case in mouse and seaurchin GV.

\section{1-3. $C A M P$ : origin and role.}

It is now well known that the increase or maintenance of high levels of cAMP in oocytes prevents meiosis resumption. This observation suggests three questions :

a) Is an adenyl cyclase present in the oocyte or is the oocyte cAMP coming from the follicular cells? 
b) Is the adenyl-cyclase/phosphodiesterase couple the target of follicular oocyte inhibitors or do all of them play a role in the maintenance of meiotic arrest?

c) Is the decrease of the CAMP level a necessary prerequisite to meiosis resumption ?

a) Contradictory conclusions have been drawn on the presence or not of an oocyte adenyl cyclase ( $\mathrm{AC}$ ), when using classical stimulatory drugs. Forskolin increases cAMP levels not only in cumulus free oocytes (mouse, Urner et al., 1983 ; Sato and Koide, 1984 ; hamster, pig, Racowsky, 1985a, b) but also in zona free ones (Bornslaeger and Schultz, 1985a). Similarly, forskolin increases CAMP in sheep (Moor and Heslop, 1981) and rat oocytes (Olsiewski and Beers, 1983). However using the same procedure Dekel et al. (1984) and Racowsky (1984) were unable to demonstrate an inhibitory effect of forskolin on rat cumulus-free oocytes.

These discrepancies in the literature could be explained by the high activity of oocyte phosphodiesterase (PDE) since oocyte PDE can in a few minutes return the CAMP to basal levels that were elevated 5 to 10 -fold before (Bornslaeger, Wilde and Schultz, 1984). Another more probable explanation come from our observations that forskolin inhibits meiosis resumption in rabbit oocytes from small antral follicles but was totally inefficient on oocytes from preovulatory follicles (table 2).

From these observations it is tempting to speculate that during final maturation oocyte adenylcyclase activity progressively disappears. This may also explain why in some species $A C$ seems incomplete due to the oocyte failure to respond to cholera toxin (mouse, Vivarelli et al., 1983 ; Bornslaeger and Schultz, 1985b) (rat, Beers and Dekel, 1981 ; Olsiewski and Beers, 1983) while sheep oocyte adenyl cyclase is stimulated by cholera toxin as well as by forskolin (Moor and Heslop, 1981 ; Crosby et al., 1985).

The second part of this question concern the possible role of follicular cells in the maintenance of oocyte cAMP level.

Experiments transferring labelled CAMP from cumulus cells to the oocyte have been unsuccessful although labelled choline or labelled uridine migrate into the oocyte (mouse, Schultz et al., 1983a, b ; Eppig and Downs, 1984 ; Sheep, Moor, Smith, Dawson, 1980 ; Crosby et al., 1985). Observations of the " natural " transfer of CAMP have been reported when cAMP level was dramatically increased in cumulus cells by both IBMX and FSH or forskolin (mouse, Bornslaeger and Schultz, 1985b ; rat, see Dekel, 1987) but it has been suggested that this apparent transfer might have been due to cAMP present in cumulus cell processes which remained embedded in the zona pellucida after the cumulus was removed (Eppig and Downs, 1984). Moroever Dekel and Beers (1978), Beers and Dekel (1981) (rat), Freter and Schultz (1984, mice) have shown that the presence of gonadotropins in the culture medium overcome the inhibitory effect of db cAMP. on cumulus enclosed oocytes (but not in cumulus free oocytes), although LH stimulates adenyl cyclase of the cumulus cells. 
Similarly repeated observations both in vivo after $\mathrm{LH}$ surge and in vitro in presence of LH have shown that CAMP level is enhanced in the follicle while oocyte cAMP decreases and meiosis resumes.

This contradictory situation has been explained by fast interruption of cumulus/oocyte coupling. This hypothesis formulated by Dekel and Beers (1978) does not fit with experimental results in mice (Eppig, 1982 ; Eppig and Ward-Bailey, 1982), hamster (Racowsky and Satterlie, 1985), sheep (Moor et al., 1980) and pig (Motlik, Fulka and Fléchon, 1986) showing that uncoupling between cumulus cells and the oocyte occurs 3 to $9 \mathrm{~h}$ after GVBD $\left({ }^{*}\right)$ and the quantitative estimation of the gap junction area by freeze fracture (Larsen et al., 1986) provide arguments favoring an interruption in granulosa and cumulus cells communication before GVBD, but not between the cumulus cells and the oocyte (Larsen et al., 1987) : the outer layer of the cumulus cells dissociate very soon whereas the internal layers remain in contact with the oocyte at least up to GVBD.

Thus the understanding of the role of uncoupling of follicular cells in meiosis resumption requires studies on the passage of nucleotides not only from cumulus cells to oocytes but from granulosa cells to cumulus cells.

b) There is no indication in the literature of a regulation of the CAMP content of oocytes by a direct stimulation or inhibition of oocyte AC/PDE by OMI(s). Generally the inhibitory activity of OMI(s) was studied either by maintaining a critical level of cAMP in such a way that $50 \%$ of oocytes remained in GV or by using a population of sub-competent oocytes in which 10 to $40 \%$ of them remain in GV during culture. Increase of this percentage is the criterion for measuring OMI activity. Although these conditions are particularly favorable for studying the effect of inhibitors on cAMP levels, to our knowledge no valuable information has been published. The question remains open.

c) The last question is : is the decrease of oocyte cAMP a prerequisite to meiosis resumption? During the maturation of mouse oocyte in vivo a close relationship exists between the drop of cAMP content and the resumption of meiosis (Schultz, Montgomery and Belanoff, 1983). The same correlation has been described in rat oocytes (Dekel, 1987). On the contrary the content of CAMP in sheep oocyte, rises during the first hour of culture of the follicle in presence of $\mathrm{FSH}$ and $\mathrm{LH}$. Then the content declines to a minimum level at the period of the GVBD (Moor and Heslop, 1981).

It is not sure that this apparent difference between the two groups of species reflect two types of biochemical mechanisms. It is tempting to relate the rapid fall of CAMP in mouse and rat oocytes to the short interval between meiosis commitment and GVBD and the first rise of cAMP in sheep oocytes to the delayed GVBD in those oocytes. To determine the importance of the CAMP fall in the resumption of meiosis in mammalian oocyte, it would be necessary to further analyse the CAMP profiles in pig or primate oocytes, in wich the GVBD is delayed the longest (table 1).

(*) Uncoupling is temporally related to the mucification of the cumulus cells lying immediately adjacent to the oocyte (mouse, Eppig and Ward-Bailey, 1982). Nevertheless if cumulus expansion is prevented by addition of heparin, FSH causes uncoupling (Salustri and Siracusa, 1983). 
TABLE 1

Chronology of oocyte maturation in vivo in some mammals

\begin{tabular}{|c|c|c|c|c|}
\hline Species & $\begin{array}{c}\text { Induction : } \\
\quad \mathrm{LH} \text { peak or } \\
\text { culture }\end{array}$ & $\begin{array}{c}\text { cAMP } \\
\text { decrease }\end{array}$ & $\begin{array}{l}\text { Chromosome } \\
\text { formation } \\
\text { and GVBD }\end{array}$ & $\begin{array}{l}\text { Full formed } \\
\text { metaphase II }\end{array}$ \\
\hline $\begin{array}{l}\text { Rat ....... } \\
\text { Mouse .... } \\
\text { Hamster ... } \\
\text { Rabbit .... }\end{array}$ & $\begin{array}{l}{ }^{*} \ldots \ldots \ldots \ldots \\
{ }^{*} \ldots \ldots \ldots \ldots \\
{ }^{*} \ldots \ldots \ldots \ldots \\
\ldots \ldots \ldots\end{array}$ & $\begin{array}{l}\ldots 1-2 \mathrm{~h} \\
\ldots 1-2 \mathrm{~h} \\
\ldots . ? \\
\ldots .\end{array}$ & $\begin{array}{l}\ldots 2.5-3 h \\
\ldots 2.5-3 h \\
\ldots \quad 3 h \\
\ldots \quad 3-4 h\end{array}$ & $\begin{array}{rr} & 10 \mathrm{~h} \\
\therefore \quad & 11-12 \mathrm{~h} \\
11-12 \mathrm{~h} \\
. \quad 9-10 \mathrm{~h}\end{array}$ \\
\hline $\begin{array}{l}\text { Sheep } \\
\text { Sheep } \\
\text { Bovine } \\
\text { Pig ... }\end{array}$ & 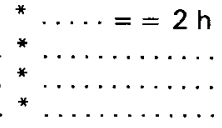 & $\begin{array}{l}\ldots \ldots++ \\
\ldots 2-9 h . \\
\ldots ?+\ldots \\
\ldots \ldots++\end{array}$ & $\begin{array}{l}+ \\
\ldots 8-11 \mathrm{~h} \\
\ldots 6-10 \mathrm{~h} \\
++\end{array}$ & $\begin{array}{l}\ldots 22-24 \text { h } \\
\ldots \quad 22-24 \text { h }\end{array}$ \\
\hline $\begin{array}{l}\text { Pig } \ldots . . . \\
\text { Macaca } \ldots \\
\text { Human } \ldots\end{array}$ & $\begin{array}{l}{ }^{*} \ldots \ldots \\
{ }^{*} \ldots \ldots \\
{ }^{*} \ldots \ldots\end{array}$ & $\begin{array}{lll}\ldots & ? & \ldots \\
\ldots & ? & \cdots \\
\ldots & ? & \end{array}$ & $\begin{array}{l}\ldots \quad 15-16 \mathrm{~h} \\
\ldots \quad 18-20 \mathrm{~h} \\
\ldots \quad 18-20 \mathrm{~h}\end{array}$ & $\begin{array}{l}30-36 h \\
28-30 h \\
30-32 h\end{array}$ \\
\hline
\end{tabular}

$===$ obligatory RNAs synthesis $;++++$ obligatory protein synthesis.

1-4. Oocyte meiosis-inhibitory factor(s), OMI, of granulosa cells.

\section{1-4-1. Cytological evidence that cAMP is not the only factor involved in meiotic arrest.}

Forskolin, IBMX and papaverine prevent the rupture of the nuclear enveloppe and the spindle formation but not the complete condensation of the chromosomes which become similar to metaphase chromosomes.

As previously described the importance and the shape of the intercellular relationships between corona cells and oocyte are different in different mammals. They are also different at various stages of oocyte maturation. In the mouse it is very difficult to establish stages of oocyte maturation dependent changes because of the superficial and relatively labile nature of the junctional corona-oocyte complexes. On the contrary when corona cell foot processes indent deeply the oocyte cell membrane (pig, cattle, sheep and rabbit) and meiosis resumption takes a longer time, maturation-related changes are more easily analysed. Prior to meiosis commitment (mating in the rabbit ; beginning of culture of cumulusoocyte complexes (COC) in presence of gonadotropins in sheep and cow), the corona cell attachments are yet complete and indent several microns deeply the oocyte cortex when bivalent stage is reached (approximately $2 \mathrm{~h}$ post coitum in rabbit and after 5-7 $\mathrm{h}$ of culture of cow and sheep COC). At this moment profound changes are visible by immunofluorescence techniques in the rat corona cell processes (Dekel, 1987). The junctions were reduced to a small area between the tip of the foot processes and cone shape evaginations of the oocyte cortex form probably resulting from the forces generated by the withdrawal of the corona cell processes, the strength of the intercellular adhesion mechanism and the elastic properties of the oocyte cortex. Two hours later, when compact chromatin mass in formed near the GVBD, the junctions between the two cells 
become rare and freely terminating corona cell processes are seen within the perivitelline space. (Szöllösi, unpublished, fig. 1).

\section{1-4-2. Nature and role of OMI.}

As pig follicular fluid is easily available and significantly reduced the percentage of spontaneous nuclear maturation of pig, rat (Tsafriri and Channing, 1975) and hamster oocytes (Gwatkin and Andersen, 1976), this material has been subjected to many types of fractionation. The results have been rather confusing and Channing et al. (1982) have concluded that there are probably two and possibly three OMI polypeptides present in pig follicular fluid which are not speciesspecific. This question has been recently revewed by Tsafriri and Pomerantz (1986) and Tsafriri (1987).

Unfortunately other groups have not been able to show that crude porcine or bovine follicular fluid, or purified fractions of these, have any inhibitory effect on the resumption of meiosis in cow, pig and rat oocytes (Liebfried and First, 1980 a ; Racowsky and McGaughey, 1982 ; Flemming et al., 1983). Moroever Sato and Ishibashi (1977), Liebfried and First (1980b) concluded, as we did, that inhibition of meiosis is only observed in vitro when there is close adherence between cumulus and granulosa cells. That means that the granulosa cells maintain the oocyte in the meiotic arrest through gap junctions or at least by close apposition of their plasma membranes.

Following different technical procedures (charcoal extraction, ion exchange chromatography and HPLC), Downs and Eppig (1985) reported that purine bases and purine nucleosides, present in porcine and mouse follicular fluids, seem responsible for follicular inhibition of meiosis. When two of these, hypoxanthine and adenosine, are present in the culture medium at the same concentration as in the follicle in vivo, they almost completely inhibit the GVBD in preovulatory mouse oocytes (Eppig et al., 1985). However, the levels of these purines do not decrease when meiosis is resumed after hCG injection (Eppig et al., 1985). More recent studies on their uptake and metabolism have not clarified this paradoxical situation (Downs et al., 1986). We have not been able to prevent meiotic resumption of rabbit cumulus-free oocytes from preovulatory follicles when cultured in the presence of hypoxanthine and adenosine, although IBMX was used to prevent meiosis commitment during oocyte preparation. However these purines completely block meiosis resumption in rabbit oocytes from smaller follicles (table 2).

Other substances synthesized by granulosa cells seem also able either to inhibit resumption of meiosis or (at least) to enhance the effect of other inhibitors.

Anti müllerian hormone (AMH) reversibly inhibits meiotic resumption of rat oocyte in a dose-dependant manner. Inhibition is similar wheter cumulus cells are present or not. This inhibition is unrelated to oocyte cAMP level and could be active via a tyrosine kinase (Takahashi et al., 1986). However a more purified AMH did not show any inhibitory activity (Tsafriri, personal communication).

The potential inhibitory activity of glycosaminglycans, which are actively secreted up to LH surge has been tested (Sato, Ueno and Koide, 1986) but results are in contradiction with what could be expected : heparin and heparan sulfate did not enhance but reduced OMI activity.

Reproduction, Nutrition, Développement. No 5-1987. - 2 
TABLE 2

Effects of forskolin, hypoxanthine and adenosine on meiosis resumption of rabbit oocytes

\begin{tabular}{|c|c|c|c|c|c|}
\hline \multirow{3}{*}{$\begin{array}{c}\text { Duration } \\
\text { of } \\
\text { culture }\end{array}$} & \multirow{3}{*}{$\begin{array}{l}\text { Drugs } \\
\text { used }\end{array}$} & \multicolumn{4}{|c|}{ Stages of meiosis } \\
\hline & & Control & Oocytes & Experim. & Oocytes \\
\hline & & G.V. & MET I & G.V. & MET I \\
\hline $\begin{array}{r}0 \mathrm{~h} \\
6-7 \mathrm{~h} \text { : }\end{array}$ & & $10 / 10$ & 0 & & \\
\hline $\begin{array}{l}\text { Oocytes from } \\
\text { preovulatory } \\
\text { follicles }\end{array}$ & $\begin{array}{c}\text { Control } \\
\text { Forskolin } \\
\text { Hypo + Aden }\end{array}$ & $\begin{array}{l}0 / 13 \\
\ldots \ldots\end{array}$ & $\begin{array}{c}13 / 13 \\
\ldots \ldots \ldots \ldots\end{array}$ & $\begin{array}{l}4 / 42 \\
8 / 59\end{array}$ & $\begin{array}{l}38 / 42 \\
51 / 59\end{array}$ \\
\hline $\begin{array}{l}\text { Oocytes from } \\
\text { smaller } \\
\text { follicles }\end{array}$ & $\begin{array}{c}\text { Control } \\
\text { Forskolin } \\
\text { Hypo }+ \text { Aden }\end{array}$ & $4 / 25$ & $21 / 25$ & $\begin{array}{l}14 / 21 \\
28 / 30\end{array}$ & $\begin{array}{l}7 / 21 \\
2 / 30\end{array}$ \\
\hline
\end{tabular}

Oocytes were prepared in a medium containing IBMX and the drugs. Then oocytes were cultured with or without drugs in Ménézo B2 $+10 \%$ rabbit serum for 6-7 h.

When taking into account all the data it seems possible to conclude that the level of cAMP plays a key role in the control of meiotic arrest and resumption. In mammalian oocytes as well as in amphibian oocytes, there is every chance that cAMP regulates meiosis through protein kinase activity and the level of phosphorylation of the maturation protein. However, in mammalian oocytes CAMP is not the one and only factor implicated in the maintenance of the meiotic arrest. When CAMP is artificially maintained at a high level inside a competent oocyte, encompassed or not by cumulus cells, chromosomes condense but nuclear enveloppe remains unbroken although some cytoplasmic microtubules are present. Thus the dissolution of nuclear envelope is CAMP-dependent but other cytological changes involved in metaphase I formation are probably regulated by other inhibitors synthesized by granulosa cells (fig. 6 ).

The chemical nature of these inhibitors remains uncertain. Purine bases are probably able to modulate phosphodiesterase activity but are not the major inhibitory factors. We can speculate that the origin of the confusion on the molecular weight of the OMI polypeptide is that the molecules isolated from the follicular fluid are the pro-inhibitor and inactivated fragments in atretic follicles. In vivo this pro-inhibitor has either to be processed in cumulus cells perhaps into a smaller molecule which would be the true meiosis inhibiting factor or to stimulate through sumulus cell specific receptors the synthesis of the active inhibitor.

This hypothesis offers an explanation of the fact that OMI polypeptide is only active on cumulus enclosed oocytes (Hillensjö et al., 1979) and that LH or FSH hastens meiosis resumption under the same conditions (Beers and Dekel, 1978 ; Freter and Schultz, 1984). Further experiments have to discover if cumulus cells metabolize OMI polypeptide and if among the smaller peptides liberated one is able to maintain meiotic arrest (fig. 6). 
In vivo, is the commitment of meiotic resumption due to the loosening of contact between mural granulosa cells and cumulus by LH surge or are more complex mechanisms involved?

It is tempting to speculate that LH surge operates directly or not (steroids, prostaglandins, histamine, ...? ?) at four levels :

- by modifying the biochemical activity of follicular and cumulus cells in such a way that the inhibitor(s) is no longer synthesized. The change in intra follicular ratio of estradiol and progesterone is one of the well known indication of these modifications : in pig follicles cultured with gonadotropins, we found that meiosis always resumes up to $M$ II when the modification of $E / P$ ratio mimics that occurring in vivo before ovulation (Gérard et al., 1979, table 1);

- by suppressing cumulus cell capacity to process or synthezise the inhibitor in its active form ;

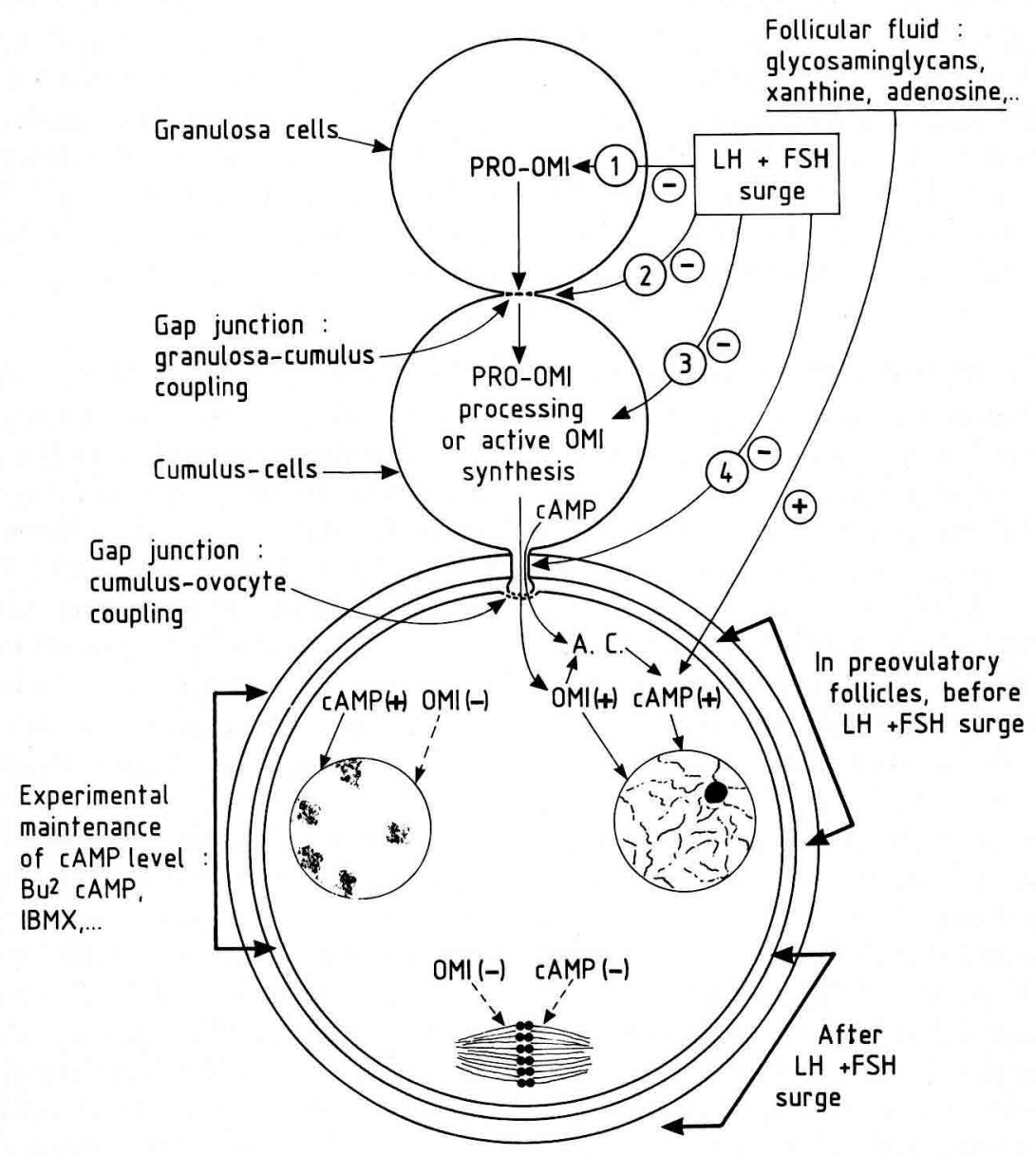

FIG. 6. - For explanation see text. 
- by dissociating cumulus cells from granulosa layer;

- by modifying the cytoskeleton of cumulus cell processes followed later on by oocyte-cumulus separation.

\section{2. - Are stimulatory factors necessary to meiosis resumption in mammals?}

\section{2-1. Culture conditions.}

Whatever the stage of competent oocytes, the percentage of them reaching M I or M II is higher when culture medium contains fetal or adult blood serum (cattle, Sreenan, 1970 ; sheep, Quirke and Gordon, 1971 ; rabbit, unpublished results). As described previously blood serum enhances cumulus and corona cells survival and it is likely that its beneficial effect on meiosis resumption is indirect through corona cells. It is unknown if serum effect is related to corona cell steroidogenesis by HDL/LDL-cholesterol supply or if serum helps corona cells to furnish energy metabolites to the oocyte. When these culture conditions are used the time schedule from meiosis commitment to $\mathrm{M} \mathrm{II}$ is similar to that observed in vivo excepting a one hour lead in case of small rodent and rabbit oocytes and few hours in species with a longer GVBD delay (4 h, pig, Motlik and Fulka, 1976). Thus studies on meiosis stimulation or inhibition need special care not always mentioned or taken in many works.

\section{2-2. Do steroids play a role in the resumption of meiosis in mammals?}

Mammalian oocytes spontaneously resume meiosis when they escape the inhibition by granulosa cells whereas fish and amphibian oocytes need the posttranscriptional trigger stimulus of C 21 steroids. However the difference is probably not so well delineated : the follicle free Xenopus oocyte resumes meiosis more rapidly than the follicle enclosed one $(4.30 \mathrm{~h} / 8 \mathrm{~h}$, Mulner and Ozon, 1981); during the sexual season, amphibian oocytes may resume meiosis « spontaneously » when released from the follicle cells showing that when critical progesterone levels are reached meiosis inhibition is maintained by follicular cell inhibitors (Vilain, Moreau and Guerrier, 1980), as in mammalian oocytes. The same observation was made many decades ago in the starfish oocyte (Delage, 1902).

In contrast, stimulation of meiosis resumption by steroids has never been proven in mammals. Conflicting results have been reported on the effect of progesterone : either there was a lower incidence of maturation in denuded mouse oocytes (Eppig and Koide, 1978) and of corona enclosed rabbit oocytes (Smith et al., 1978), or an enhancement of nuclear maturation of cumulus enclosed rabbit oocytes (Bae and Foote, 1975). A negative effect on pig oocytes of oestradiol (McGaughey, 1977) and androgens (Rice and Mc Gaughey, 1981), has been described in in vitro studies. Similarly Daniel et al. (1986) concluded that testosterone and 19 nor-testosterone inhibit porcine oocyte nuclear maturation ; however this effect is only observed after $12 \mathrm{~h}$ of culture but neither at $6 \mathrm{~h}$ nor at $24 \mathrm{~h}$. 
The effectiveness of the role of steroids has been studied either by inhibiting steroidogenesis or by injecting antibodies against steroids in maturing conditions :

- Anti-progesterone antibodies given with hCG to PMSG pretreated rats decrease significantly the percentage of oocytes in GVBD $6 \mathrm{~h}$ after hCG but the pourcentage of GVBD in control rats is low (68\%) (Mori et al., 1983). With the same experimental procedure, anti-oestrone antibodies slightly enhance GVBD in oocytes from large follicles (Mori et al., 1979).

- There is general agreement that inhibitors of the key enzymes of steroidogenesis laminogluthetimide : cholesterol $\rightarrow$ P5 ; cyanoketone, trilostane : P5 $\rightarrow \mathrm{P} 4$; SU $10603: \mathrm{P} 4 \rightarrow 17 \alpha \mathrm{OHP} 4 ; 4-\mathrm{OH} \Delta 4: \mathrm{T} \rightarrow \mathrm{E} 217 \beta)$ do not impair the resumption of meiosis in follicle enclosed oocytes (rat, Liberman et al., 1976 ; Billig et al., 1983). Similarly trilostane has no effect on meiosis resumption of cumulus enclosed or naked hamster oocytes (Suzuki et al., 1984).

However aminoglutethimide reduces the percentage of pig oocytes which reach M II (31 \% vs $69.5 \%$, Szöllösi and Gérard, 1983) and $17 \alpha$-hydroxylase inhibition, even if estradiol is present in the medium, prevents the passage of sheep oocytes from M I to M II. Osborn, Moor and Crosby (1986) concluded that testosterone or progesterone/testosterone ratio plays a role on the final maturation of sheep oocytes by regulating synthesis of proteins involved in final meiotic processes.

The role of steroids in meiosis achievement of mammalian oocytes will remain controversial till antireceptors or specific antagonists are used.

\section{2-3. Are late RNA and protein synthesis a prerequisite to meiosis resumption.}

In pig oocyte GVBD is only observe 14 to $16 \mathrm{~h}$ after the beginning of the culture. Because of this long delay the importance in meiosis achievement of protein synthesis, 6 to $12 \mathrm{~h}$ after the beginning of the culture, is obvious (Fulka et al., 1986). Similarly in sheep oocyte a peptide of $47 \mathrm{KD}$ is synthesized 6-8 $\mathrm{h}$, after the beginning of the culture, i.e. $2 \mathrm{~h}$ before the GVBD, and the inhibition of this synthesis with cycloheximide prevents GVBD; this peptide is dependant on a RNA synthesized during the two first hours of the culture (Moor and Crosby, 1986). (It is interesting to remember that a peptide of $48 \mathrm{KD}$ appears in the Xenopus oocyte in response to progesterone). In contrast, GVBD occurs in mouse oocyte when either protein synthesis (Fulka et al., 1986) or RNAs synthesis ( $\alpha$ amanitine or actinomycin D, Crozet and Szöllösi, 1980) is inhibited. However the inhibition of meiosis resumption with dbcAMP modifies peptide profiles (Richter and McGaughey, 1981). These contradictions may result from the lack of care taken to avoid meiosis reinitiation from being engaged before the drugs could stop synthesis. This is the case when meiosis resumes very rapidly as in rodent oocytes. In fact, Ekholm and Magnusson (1979) have shown that when rat oocytes are precultured for 1 to $4 \mathrm{~h}$ in a medium with dbcAMP + cycloheximide and then cultured further, cycloheximide alone significantly reduces the percentage of meiotic resumption.

Even when cycloheximide or actinomycin D does not inhibit GVBD in mouse oocyte, meiosis stops at metaphase I, showing that some early RNA synthesized before GVBD leads to the presence of polypeptides involve in the achievement of 
meiosis (Golbus and Stein, 1976). Moroever Clarke and Masui (1983, 1985) demonstrate that the block at metaphase II also needs active protein synthesis, whereas in presence of puromycine, $\mathrm{M} /$ oocytes extrude the first polar body but forme a pronucleus and not a metaphase II plate. Fused with M II oocytes these " nucleated » oocytes return to the $\mathrm{M}$ II stage. When zona free mouse oocytes are fertilized at prometaphase I or at M I, sperm chromatin slightly decondensed but male pronucleus did not form and progressively sperm « metaphase " chromosomes may appear. This gives a supplementary proof that a factor present in the cytoplasm of maturing oocyte is required for the maintenance of meiotic spindle and chromosomes (Clarke and Masui, 1986).

\section{Cytoplasmic maturation}

\section{A. - Oocyte cytological changes during final maturation.}

\section{1. - Cytoplasmic organelles.}

Cytoplasmic organelles are scattered fairly uniformly through the ooplasm in ovarian oocytes, even though clear cytoplasmic islets are also seen, in toluidine blue stained semi-thin sections and by electron microscopy. Following maturation induction, at the time of circular bivalent stage formation and initiation of GVBD, mitochondria aggregate around the GV and form mitochondrial halo around it. Nocodazol treatment, a potent inhibitor of microtubules, indicates that microtubules are implicated in the mitochondrial dislocation. Following expulsion of the first polar body the mitochondria disperse more uniformly and once more aggregate during the arrested metaphase II stage (Van Blerkom and Runner, 1984 ; Van Blerkom and Bell, 1986). In case mitochondrial clustering does not occur, maturation is arrested at metaphase I, evidently lacking the necessary energy source.

Cortical and perinuclear distribution also of the Golgi elements varies during the maturation processes. The GV is surrounded by a continuous halo of Golgi units. The cortical Golgi units are large and placed in the proximity of the attachement sites of the corona cell foot processes (Moricard and Moricard, 1975). It is tempting to imply a direct functional relationship of the proximity of these two structures, particularly in view of the recent demonstration that molecular passage is possible between the two cell types at the junctional complex level (Moor et al., 1980). In the proximity of the cortical Golgi units large accumulation of cortical granules form clusters where the individual granules are in different condensation and maturation stages. These local associations are retained until just about the time of the GVBD (Szöllösi et al., 1978). At which time the Golgi units initiate cortical granules production in oogenesis has not been systematically studied, although some CGs are formed early during initiation of cytoplasmic growth.

The cortical granules become uniformely electron dense in the clusters and then are distributed to form an irregularly placed monolayer of a few nanometer distance from the cell membrane at about the time of ovulation (Cran and Cheng, 1985). The CGs are distributed throughout the entire inner surface of the sphere 
of the oocyte. A small bundle of actin filament layer is often interposed between the plasma membrane and the membrane limiting the CG in preovulatory oocytes.

In ovarian oocytes no perivitelline space exits but it develops when polar body extrusion takes place. A loss of oocyte volume occurs at that time. In oocytes of some mammals (human, pig, sheep) adjacent to plasma membrane a cytoplasmic zone of several micron thickness develops which lacks in general organelles.

\section{2. - Mitochondria.}

In oocytes of every mammal so far studied by electron microscopy, oocyte specific mitochondria are found. They are usually spherical or ovale in shape and possess a dense matrix. They have irregularly placed cristae which are peripheral, parallel to the outer mitochondrial membrane. A large clear vesicle occupied a part of the matrix. Flattened smooth endoplasmic reticulum (sER) vesicles associate regularly with the mitochondria. An unusual, special sER-mitochondria complex is found in ungulate oocytes, which posses " hooded " mitochondria. The SER vesicles associated preferentially with the narrow space formed between the " hood" and the principal part of the mitochondria (Szöllösi, 1972).

It is not known if the special morphological arrangements reflect a specialized mitochondrial functional pattern in mammalian oocytes. During early cleavage stages a structural reorganization is initiated and the cristae become more conventional, projecting perpendicularly to the long axis of the organelle while the matrix looses its high density and become polymorph. An important observation is that the mitochondria of paternal origin swell shortly after sperm penetration and degenerate more (human) or less rapidly (sheep). The zygote mitochondria thus are of maternal origin and inheritance.

\section{3. - Vitellus (Yolk substance).}

Mammalian oocytes are considered as " a vitellin ", that is they would not contain yolk. It is difficult to conceive of a large cell, like that of an oocyte, to find no reserve substances, particularly in view of its low synthetic activities during early embryogenesis. The difficulties concerning this point are rather semantic than fundamental. Most problems of early embryology have been studied either in amphibian or avian species and various marine invertebrates with a well developed yolk platelet system. Yolk may be composed either of carbohydrates, proteins or lipids (phospholipids) mostly organized into a membrane bound organelle (Szöllösi, 1972).

In the sense of the above definition no true yolk is found is mammals. In fact, the meaning of the term yolk must be expanded and used in the sense of deposit of energy rich substances which are utilized before the production of the same is possible by the developing embryo.

Such substances may be organized into paracrystalline materials encountered in several rodent oocytes and in giant lipid droplets of carnivore oocytes. Vitelline substances develop to a much lesser extent in most other mammalian oocytes studied ; glycogen deposits and a variety of membrane bounded cytoplasmic vesi- 
cles were observed in rabbit, ungulate and human oocytes. Since the latter vesicles are frequently associated with dispersed small ribosomal clusters, the vesicles represent a specialized compartment of the rough ER (rER) (Szöllösi, 1971).

The accumulation and control of uptake of the molecules composing them must be studied more actively in mammals. It is very likely that, with amphibian oocytes the uptake of yolk precursors as the intracellular entrance of macromolecules from somatic cells, the coated pits play an active role while the coated vesicles participate in the intracellular transport and formation of « yolk platelet ".

\section{B. - Physiological role of mural granulosa and cumulus.}

Two cell populations are involved in cytoplasmic maturation, those of the mural granulosa and those of the cumulus. Their respective role must be distinguished. Isolation of pure cumulus cell-oocyte complexes is easy in the rabbit follicle since cumulus is topographically distinguishable of granulosa cell layer in unstimulated follicle. On the contrary in most other mammalian species cumulus cells spread over the mural granulosa without visible delineation and the recovery of granulosa-free cumulus complexes is uncertain.

\section{1. - Granulosa cell functions.}

Fifteen years ago we discovered the importance of granulosa cells in the cytoplasmic maturation of rabbit oocytes (Thibault and Gérard, 1970, 1973). When cumulus enclosed oocytes were matured outside their follicle, sperm nuclear decondensation did not follow the normal sequence and further development of the zygote was impaired. Our observations were roughly confirmed by Motlik and Fulka (1974b) who extended them to pig oocytes (1974a). In vitro matured cumulus enclosed bovine oocytes behave similarly (Thibault, Gérard and Ménézo, 1975, 1976). Even when a male pronucleus develops after fertilization, regular cleavage seldom occurs lovine, Moor and Trounson, 1977; bovine, Trounson et al., 1977 ; Liebfried-Rutledge et al., 1986).

In vivo maintenance of rabbit oocytes inside their follicle at increasing time after mating or hCG injection, before complementary culture, showed that cytoplasmic competence was completely acquired during the first six hours after reinitiation of meiosis and therefore after GVBD (Chang, 1955 ; Thibault and Gérard, 1973). Similarly changes in protein synthesis during in vivo or in vitro intrafollicular maturation of ovine oocytes occurs between 6 to $15 \mathrm{~h}$ after increase of LH, that is before and after GVBD; but the protein profile remains unchanged if meiosis resumption occurs outside the follicle (Warnes, Moor and Johnson, 1977). Slight differences in peptide profiles has also been observed in rabbit oocytes matured either in vivo or in vitro (Van Blerkom and McGaughey, 1978). Thus oocyte's ability to decondense sperm nucleus depends of or is related to new protein synthesis.

The successful co-culture of cumulus-enclosed oocytes and granulosa cells have proved the basic role of these cells in the acquisition of oocyte cytoplasmic competence at the final stages of its maturation (rabbit, Motlik and Fulka, 1982 ; 
ovine, Staigmiller and Moor, 1984 ; Crozet et al., 1987 ; bovine, Critser et al., 1986).

All these results establish that the complete physiological maturation of oocytes in these mammalian species requires both a granulosa cell dependent inductive phase, during which these cells initiate changes within the oocyte and a follicle-independant synthetic phase in which protein changes, initiated in the inductive phase, are completed. The nature of instructional signals is unknown however there are indications that steroid levels (mainly estradiol) and ratios are concerned : abnormal patterns of protein synthesis and of male pronucleus formation have been observed when the steroid profiles are altered during the critical, 6 to $8 \mathrm{~h}$, inductive phase of cytoplasmic maturation of sheep oocytes (Moor and Osborn, 1983 ; Osborn and Moor, 1983). This conclusion fits well with the observations of Soupart (1975) who showed that normal male pronucleus formation only occurred in human oocytes when estradiol and then estradiol plus $17 \alpha \mathrm{OH}$ progesterone were added sequentially in the culture medium. We have also shown that estradiol and testosterone further cytoplasmic maturation of rabbit oocytes (Thibault et al., 1975).

In conclusion, the presence of granulosa cells is absolutely necessary at the beginning of the final oocyte maturation in sheep, bovine, pig and rabbit. These cells initiate protein and/or polypeptide synthesis which render the cytoplasm competent to assume normal cooperation with the male genome. This conclusion does not concern rodent oocytes since after in vitro maturation cumulus enclosed rat and mouse oocytes, or even denuded mouse oocytes, are fertilizable and can initiate full development up to birth (rat, Flemming et al., 1985 ; mouse, Schroeder and Eppig, 1984 ; Downs et al., 1986). Schroeder and Eppig have suggested that their success resulted from an improvement of the culture conditions ; since Flemming et al. obtained normal rat embryos without the same refining conditions, it is more probable that difference is related to species specifity.

\section{2. - The role of cumulus cells.}

If we turn again to the aptitude of in vitro matured oocytes to rapidly decondense sperm nuclei, there is a discrepancy between our results and those of other laboratories. They found there was always a proportion (50 to $90 \%$ ) of oocytes capable to normally decondense the sperm nucleus (Liebfried-Ruttledge et al. 1985, 1986) while we never observed a fast and complete decondensation. This difference may proceed from the inclusion or not of granulosa cells within the cumulus-oocyte complexes and the presence or not of gonadotropins in the culture medium. Gonadotropins and mainly FSH induce cumulus expansion and hasten the rupture between cumulus cells and oocyte; Eppig (1982a) has clearly demonstrated that the longer the cumulus cells remain attached to the oocyte the higher is the percentage of parthenogenetic development in a sensitive mouse strain. Thus as we always culture both rabbit and bovine oocytes with FSH and collected pure cumulus mass, especially in rabbit follicle, the absence of normal decondensation in all of our experiments might be explained.

Is it due to an increase of the whole metabolism of the oocyte better supplied in metabolites by cumulus-granulosa cells ? This point remains to be determined. 


\section{III. - Membrane competence}

In most mammalian oocytes zoological specificity operates at the zona level. Sperm specifically bind to the zona pellucida through the linkage of the glucid moiety of a zona glycoprotein (ZP3) and sperm plasma membrane glycosyl residues. Then the attachment to the peptide moiety (Wassarman, 1987) generally induces the acrosome reaction which had been shown to occur on the zona (Gwatkin and Andersen, 1976 ; pig, Szöllösi and Hunter, 1973 ; mice, Florman and Storey, 1982 ; bovine, Crozet, 1984 ; ovine, Crozet and Dumont, 1984 ; human, Overstreet et al., 1987).

Although zona pellucida is deposited during oocyte growth, its aptitude to be recognized by sperm is not always acquired at this moment; if rabbit oocytes from preantral follicles are recognized and penetrated in vitro by in vivo capacitated sperm, in sheep, follicles must reach $2 \mathrm{~mm}$ before oocytes can be penetrated by capacitated sperm in oviduct of an oestrus-mated ewe (Crozet and Dumont, 1984).

Follicular cells and/or cumulus cells are involved in the acquisition of the chemical specificity of the zona. Naked rat oocytes matured in vitro are of lower fertilizability than oocytes maturing in their cumulus 12 vs $32 \%$, Flemming et al., 1985). Similarly denuded mouse oocytes are less fertilizable than those matured in their cumulus (35 vs $78 \%$, Schroeder and Eppig, 1984. No fertilization occurs when hamster cumulus-enclosed oocytes are matured outside their follicle, whereas control oocytes matured in vitro inside their follicles are fertilizable 10 vs $62 \%$ ). This fertilizing ability is acquired 2 to $4 \mathrm{~h}$ after induction of ovulation (Plachot and Mandelbaum, 1978).

\section{Conclusions.}

Achievement of meiosis is only one aspect of oocyte maturation. Cytological changes as well as the synthesis and storage of RNAs and proteins are also a prerequisite of the normality for the fertilization process and cleavage. Furthermore the molecules involved in sperm-egg specific attachement are present in the zona pellucida and on the plasma membrane more or less early according to the species and sometimes many days after the deposit of the zona pellucida and the complete growth of the oocyte. Most of the cytoplasmic changes related to the final maturation are only achieved a few hours before ovulation.

Granulosa cells and cumulus cells play a fundamental role in the oocyte growth, the acquisition of meiotic competence and then the block of meiosis attainment and in all steps of cytoplasmic and membrane maturation except for the last ones in rat and mouse oocytes.

The meiosis block results of the cooperative effects of two or three inhibitors : OMI peptides, cAMP and possibly purine nucleosides. During the few 
days or hours preceding gonadotropin surge, efficiency of inhibitors decrease as shown by in vitro studies with oocytes from preovulatory or smaller follicles.

Steroid levels and ratio are involved in cytoplasmic maturation but their role in meiosis block and resumption has never been demonstrated. Although cytological picture and polypeptide profiles give valuable data on the status of oocyte maturity after in vitro culture, the only indisputable criteria at present are normal cleavage and embryonic development up to birth. This has been only obtained up to now, with similar percentages than after in vivo maturation with rat, mouse and sheep oocytes.

Reçu en mai 1987. Accepté en juillet 1987.

\section{Résumé. La maturation de l'ovocyte des Mammifères.}

La reprise de la méiose de l'ovocyte de Mammifère qui se produit après la décharge gonadotrope ovulante dans le ou les follicules préovulatoires, est également observée quand l'ovocyte est cultivé, même sans gonadotropines. Cependant ces expériences in vitro montrent que seuls les ovocytes qui ont atteint les $3 / 4$ de leur taille finale sont " compétents " pour reprendre leur méiose. Ce sont les cellules folliculaires qui en assurant la croissance de l'ovocyte le rendent compétent. A ce moment les cellules internes du follicule qui forment la granulosa s'opposent à cette potentialité et ce jusqu'à la décharge gonadotrope qui modifie fondamentalement leur activité permettant ainsi la reprise de la méiose.

II paraît exister trois types de facteurs inhibiteurs :

- un ou plusieurs peptides appelés OMI (Oocyte meiosis inhibitor) ;

- l'AMP cyclique synthétisé par l'ovocyte tout au moins pendant toute une partie de la croissance du follicule a antrum ; I'AMPc peut également être apporté à l'ovocyte par les cellules folliculaires ;

- un ou plusieurs nucléosides puriques présents dans le liquide folliculaire.

A la lumière de nos études cytologiques et de nos résultats expérimentaux avec différentes drogues connues pour intervenir sur le taux d'AMPc intraovulaire il apparaît, au moins chez les Ruminants et le lapin, que des changements nucléaires et cytoplasmiques d'une part, une perte de sensibilité vis-à-vis des facteurs inhibiteurs d'autre part, se produisent bien avant la décharge ovulante dans les ovocytes des plus gros follicules.

Parallèlement à la reprise de la méiose s'effectue une maturation cytoplasmique qui s'accompagne d'un changement dans les synthèses protéiques auquel contribuent les cellules de la granulosa et, dans certains cas, celles qui entourent directement l'ovocyte, les cellules du cumulus. Seule la culture de l'ovocyte dans son follicule en présence de gonadotropines ou la co-culture de cellules de granulosa avec le complexe cumulusovocyte, permet après fécondation in vitro un développement embryonnaire complet jusqu'à la naissance. Dans ces conditions, chez la Brebis le pourcentage d'œufs maturés in vitro qui se développent est semblable à celui observé, dans les mêmes conditions, avec des ovocytes maturés normalement in vivo.

L'ovocyte de Souris et celui de Rat disposent d'une beaucoup plus grande autonomie vis-à-vis des cellules folliculaires pour parfaire leur maturation.

Enfin, au cours de la maturation de l'ovocyte se produisent dans la membrane pellucide des changements moléculaires dans sa composition qui permettent au spermatozoïde de l'espèce de $s^{\prime} y$ fixer spécifiquement. II en est probablement de même chez la plupart des Mammifères, au niveau de la membrane plasmique. Selon les espèces ces changements membranaires se produisent plus ou moins rapidement après la formation de la membrane pellucide : presque aussitôt chez la lapine, très tardivement chez le hamster et, dans ce cas, les cellules folliculaires sont également impliquées. 


\section{Références}

AMSTERDAM A., LINDNER H. R., GRÖSCHEL-STEWART U., 1976. Localisation of actin and myosin in the rat oocyte and the follicular wall by immunofluorescence. Anat. Rec., 187, 311328.

ANDERSON E., 1972. The localization of acid phosphatase and the uptake of horse-radish peroxydase in the oocyte and follicle cells of mammals, 87-117. In BIGGERS J. D., SCHUETZ A. W., Oogenesis, Univ. Park Press, Baltimore.

ANDERSON E., 1977. Junctional complexes in the developing ovarian follicle and the preimplantation mammalian embryo with particular reference to gap junction. Res. Reprod., 9, $\mathrm{N}^{\circ} 5$.

ANDERSON E., ALBERTINI D. F., 1976. Gap junctions between the oocyte and companion follicle cells in the mamalian ovary. J. Cell Biol., 78, 58-75.

BACHVAROVA R., BARAN M. M., TEJBLUM A., 1980. Development of naked growing mouse oocytes in vitro. J. exp. Zool., 211, 159-169.

BACHVAROVA R., DE LÉON V., 1977. Stored and polysomal ribosomes in mouse ova. Develop. Biol., 58, 248-254.

BACHVAROVA R., DE LÉON V., JOHNSON A., KAPLAN G., PAYNTON B. V., 1985. Changes in total RNA, polyadenylated RNA, actin mRNA during meiotic maturation of mouse oocytes. Develop. Biol., 108, 325-331.

BAE I.-H., FOOTE R. H., 1975. Effects of hormones on the maturation of rabbit oocytes recovered from follicles of various sizes. J. Reprod. Fertil., 42, 357-360.

BAR-AMI S., TSAFRIRI A., 1981. Acquisition of meiotic competence in the rat : role of gonadotropin and estrogen. Gamete Res., 4, 463-472.

BATTAGLIA D. E., GADDUM-ROSSE P., 1986. The distribution of polymerized actin in the rat egg and its sensitivity to cytochalasin B during fertilization. J. exp. Zool., 237, 97-105.

BEERS W. H., DEKEL N., 1981. Intercellular communication and the control of oocyte maturation. In Dynamics of ovarian function, 95-104. SCHWARTZ N. B., HUNZICKER-DUNN M., Raven Press, N. Y.

BILLIG H., HILLENSJO T., TSAFRIRI A., MAGNUSSON L., BRODIE A., 1983. Nuclear maturation of follicle-enclosed rat oocytes during inhibition of steroidogenesis. Gamete Res., 8, 79-86.

BLEIL J. D., WASSARMAN P. M., 1980. Synthesis of zona pellucida proteins by denuded and follicle-enclosed mouse oocytes during culture in vitro. Proc. nat. Acad. Sci., USA, 77, 10291033.

BORNSLAEGER E. A., SCHULTZ R. M., 1985a. Adenylate cyclase activity in zona-free mouse oocytes. Exp. Cell Res., 56, 277-281.

BORNSLAEGER E. A., SCHULTZ R. M., 1985b. Regulation of mouse oocyte maturation : effect of elevating cumulus cell cAMP on oocvte cAMP levels. Biol. Reprod., 33, 698-704.

BORNSLAEGER E. A., WILDE M. W., SCHULTZ R. M., 1984. Regulation of mouse oocyte maturation : involvment of cyclic AMP phosphodiesterase and calmodulin. Dev. Biol., 105, 488 499.

BUCCIONE R., CECCONI S., TATONE C., MANGIA F., COLONNA R., 1987. Follicle cell regulation of mammalian oocyte growth. J. exp. Zool., 242, 351-354.

CALARCO P. G., 1972. The kinetochore in oocyte maturation, 65-89. In BIGGERS J. D., SCHUETZ A. W., Oogenesis, Univ. Park, Pennsylvania.

CALARCO P. G., DONAHUE R. P., SZÖLLOSI D., 1972. Germinal vesicle breakdown in the mouse oocyte. J. Cell Sci., 10, 369-385.

CANIPARI R., PALOMBI F., RIMINUCCI M., MANGIA F., 1984. Early programming of maturation competence in mouse oogenesis. Develop. Biol., 102, 519-524.

CHANG M. C., 1955. Fertilization and normal development of follicular oocytes in the rabbit. Science, 121, 867-869.

CHANNING C. P., ANDERSON L. D., HOOVER D. J., KOLENA J., OSTEEN K. G., POMERANTZ S. H., TANABE K., 1982. The role of the nonsteroidal regulators in control of oocyte and follicular maturation. Rec. Progr. Horm. Res., 38, 331-408.

CLARKE H. J., MASUI Y., 1983. The induction of reversible and irreversible chromosome decondensation by protein synthesis inhibition during meiotic maturation of mouse oocytes. Develop., Biol., 97, 291-301. 
CLARKE H. J., MASUI Y., 1985. Inhibition by dibutyryl cyclic AMP of the transition to metaphase of mouse oocyte nuclei and its reversal by cell fusion to metaphase oocytes. Develop. Biol., 108, 32-37.

CLARKE H. J., MASUI Y., 1986. Transformation of sperm nuclei to metaphase chromosomes in the cytoplasm of maturing oocytes of the mouse. J. Cell Biol., 102, 1039-1046.

CRAN D. G., CHENG W. T. K. 1985. Changes in cortical granules during porcine oocyte maturation. Gamete Res., 11, 311-319.

CRITSER E. S., LIEBFRIED-RUTLEDGE M. L., EYESTONE W. H., NORTHEY D. L., FIRST N. L., 1986. Acquisition of developmental competence during maturation in vitro. Theriogenology, 25, 150.

CROSBY L. M., MOOR R. M., HESLOP J. P., OSBORN J. C., 1985. Cyclic AMP in ovine oocytes, localization of synthesis and its action on protein synthesis, phosphorylation and meiosis. $J$. exp. Zool., 234, 307-318.

CROZET N., 1984. Ultrastructure aspects of in vivo fertilization in the cow. Gamete Res., 10, 241251.

CROZET N., DUMONT M., 1984. The site of acrosome reaction during in vivo penetration of sheep oocyte. Gamete Res., 10. 97-105.

CROZET N., HUNEAU D., DESMEDT V., THËRON M. C., SZÖLLÖSI D., TORRĖS S., SEVELLEC C., 1987. In vitro fertilization with normal development in the sheep. Gamete Res., 16, 159-170.

CROZET N., SZÖLLÖSI D., 1980. Effects of actinomycin D and $\alpha$-amanitin on the nuclear ultrastructure of mouse oocyte. Biol. Cell, 38, 163-170.

DAGUET M. C., 1980. In vivo change in the germinal vesicle of the sow oocyte during the follicular phase before the ovulatory surge. Reprod. Nutr. Dévelop., 20, 673-680.

DANIEL S. A. J., KHALIL M. W., ARMSTRONG D. T., 1986. 19-Norandrostenedione (4-estrene-3, 17-dione) inhibits porcine oocyte maturation in vitro. Gamete Res., 13, 173-184.

DELAGE Y., 1902. Nouvelles recherches sur la parthénogenèse expérimentale chez Asterias glacialis. Archiv. Zool. exp., 10, $3^{\circ}$ sér., 213-235.

DEKEL N., 1987. Interaction between the oocyte and the granulosa cells in the preovulatory follicle. Endocr. Phys. Reprod., Plenum Press (in press).

DEKEL N., BEERS W. H., 1978. Rat oocyte maturation in vitro: relief of cAMP inhibition by gonadotropins. Proc. nat. Acad. Sci., USA, 75, 4369-4373.

DEKEL N., ABERDAM E., SHERIZLY I., 1984. Spontaneous maturation in vitro of cumulusenclosed rat oocytes is inhibited by forskolin. Biol. Reprod., 31, 244-250.

DOWNS S. M., EPPIG J. J., 1984. Cyclic adenosine monophosphate and ovarian follicular fluid act synergistically to inhibit mouse oocyte maturation. Endocrinology, 114, 418-427.

DOWNS S. M., EPPIG J. J., 1985. A follicular fluid component prevents gonadotropin reversal of cyclic adenosine monophosphate-dependant meiotic arrest in murine oocytes. Gamete Res., 11, 83-97.

DOWNS S. M., COLEMAN D. L., EPPIG J. J., 1986. Maintenance of murine meiotic arrest : uptake and metabolism of hypoxanthine and adenosine by cumulus-cell enclosed and denuded oocytes. Develop. Biol., 117, 174-183.

DOWNS S. M., SCHROEDER A. C., EPPIG J. J., 1986. Developmental capacity of mouse oocytes following maintenance of meiotic arrest. Gamete Res., 15, 305-316.

EINSPANIER R., PITZEL L., WUTTKE W., HAGENDORFF G., PREUSS K.-D., KARDALINOU E., SCHEIT K. H., 1986. Demonstration of a mRNA for oxytocin and prolactin in porcine granulosa and luteal cells. FEBS Lett., 204, 37-40.

EKHOLM C., MAGNUSSON C., 1979. Rat oocyte maturation: effects of protein synthesis inhibitors. Biol. Reprod., 21, 1287-1293.

EPPIG J. J., 1977. Mouse development in vitro with various culture systems. Develop. Biol., 60, 371-388.

EPPIG J. J., 1979. A comparison between oocyte growth in co-culture with granulosa cells and oocytes with granulosa cell-oocyte junctional contact maintained in vitro. J. exp. Zool., 209, 345-353.

EPPIG J. J., 1982a. The relationship between parthenogenetic embryonic development and cumulus cell-oocyte intercellular coupling during oocyte meiotic maturation. Gamete Res., 5, 229-237. 
EPPIG J. J., 1982b. The relationship between cumulus cell-oocyte coupling, oocyte meiotic maturation and cumulus expansion. Develop. Biol., 89, 268-272.

EPPIG J. J., DOWNS S. M., 1984. Chemical signals that regulate mammalian oocyte maturation. Biol. Reprod., 30, 1-11.

EPPIG J. J., KOIDE S. L., 1978. Effects of progesterone and oestradiol $17 \beta$ on the spontaneous meiotic maturation of mouse oocytes. J. Reprod. Fertil., 53, 99-101.

EPPIG J. J., WARD-BAILEY P., 1982. The mechanism of cumulus cell-oocyte uncoupling : evidence for the participation of both cumulus cells and oocytes. Gamete Res., 6, 145-154.

EPPIG J. J., WARD-BAILEY P., COLEMAN D. L., 1985. Hypoxanthine and adenosine in murine ovarian follicular fluid: concentration and activity in maintaining meiotic arrest. Biol. Reprod., 33, 1041-1049.

FLEMMING A. D., EVANS G., WALTON A., ARMSTRONG D. T., 1985. Developmental capability of rat oocytes matured in vitro in defined medium. Gamete Res., 12, 255-263.

FLEMMING A. D., KHALIL W., ARMSTRONG D. T., 1983. Porcine follicular fluid does not inhibit maturation of rat oocytes in vitro. J. Reprod. Fert., 69, 665-670.

FLORMAN H. M., STOREY B. T., 1982. Mouse gamete interactions : the zona pellucida is the site of the acrosome reaction leading to fertilization in vitro. Develop. Biol., 91, 121-130.

FOOTE W. D., THIBAULT C., 1969. Recherches expérimentales sur la maturation in vitro des ovocytes de truie et de veau. Ann. Biol. anim. Bioch. Biophys., 9, 329-349.

FOURCROY J. L., 1982. RNA synthesis in immature mouse oocyte development. J. exp. Zool., 219, 257-266.

FRETER R. R., SCHULTZ R. M., 1984. Regulation of murine oocyte meiosis : evidence for a gonadotropin-induced, cAMP-dependent reduction in a maturation inhibitor. J. Cell Biol., 98. 1119-1128.

FULKA J. Jr., MOTLIK J., FULKA J., JILEK F., 1986. Effect of cycloheximide on nuclear maturation of pig and mouse oocytes. J. Reprod. Fert., 77, 281-285.

GÉRARD M., MÉNÉZO Y., ROMBAUTS P., SZÖLLÖSI D., THIBAULT C., 1979. In vitro studies of oocyte maturation and follicular metabolism in the pig. Ann. Biol. anim. Bioch. Biophys., 19, $1521-1535$.

GILULA N. B., EPSTEIN M. L., BEERS W. H., 1978. Cell to cell communication and ovulation. A study of the cumulus-oocyte complex. J. Cell Biol., 78, 58-75.

GOLBUS M. S., STEIN M. P., 1976. Qualitative patterns of protein synthesis in the mouse oocyte. J. exp. Zool., 198, 337-342.

GWATKIN R. B., ANDERSEN O. F., 1976. Hamster oocyte maturation in vitro : inhibition by follicular components. Life Sci., 19, 527-536.

HILLENSJÖ T., CHANNING C. P., POMERANTZ S. H., SCHWARTZ-KRIPNER A., 1979. Intrafollicular control of oocyte maturation in the pig. In vitro, 15, 32-39.

HYTTEL P., CALLESEN H., GREVE T., 1986. Ultrastructural features of preovulatory oocyte maturation in superovulated cattle. J. Reprod. Fertil., 76, 645-656.

KAPLAN G., ABREU S. L., BACHVAROVA R., 1982. rRNA accumulation and protein synthetic patterns in growing mouse oocytes. J. exp. Zool., 220, 361-370.

KAPLAN R., DEKEL N., KRAICER P. F., 1978. Acceleration of onset of oocyte maturation in vitro by luteinizing hormone. Gamete Res., 1978, 1, 59-63.

KING W. A., BOUSOUET D., GREVE T., GOFF A. K., 1986. Meiosis in bovine oocytes matured in vivo and in vitro. Acta vet. scand., 27, 267-279.

KRUIP T. A. M., CRAN D. G., van BENEDEN T. H., DIELEMAN S. J., 1983. Structural changes in bovine oocytes during final maturation in vivo. Gamete Res., 8, 29-47.

LARSEN W. J., WERT S. E., BRUNNER G. D., 1987. Differential modulation of rat follicle cell gap junction populations at ovulation. Develop. Biol., 122, 61-71.

LIEBERMAN M. E., TSAFRIRI A., BAUMINGER S., COLLINS W. P., AHREN K., LINDNER H. R., 1976. Oocytic meiosis in cultured rat follicles during inhibition of steroidogenesis. Acta endocr., 83, 151-157.

LIEBFRIED-RUTLEDGE M. L., CRITSER E. S., FIRST N. L., 1986. Fertilization potential of follicular oocytes classified by stage of cycle and size of follicle. Theriogenology, 23, 753-759. 
LIEBFRIED-RUTLEDGE M. L., CRITSER E. S., FIRST N. L., 1986. Effects of fetal calf serum and bovine serum albumin on in vitro maturation and fertilization of bovine and hamster cumulus-oocyte complexes. Biol. Reprod., 35, 850-857.

LIEBFRIED L., FIRST N. L., 1980a. Effect of bovine and porcine follicular fluid and granulosa cells on maturation of oocyte in vitro. Biol. Reprod., 23, 699-705.

LIEBFRIED L., FIRST N. L., 1980b. Follicular control of meiosis in the porcine oocyte. Biol. Reprod., 23, 705-709.

LONGO F. J., CHEN D. Y., 1985. Development of cortical polarity in mouse eggs : involvement of the meiotic apparatus. Dev. Biol., 107, 382-394.

MCGAUGHEY R. W., 1977. The culture of pig oocytes in minimal medium and the influence of progesterone and estradiol-17 $\beta$ on meiotic maturation. Endocrinology, 100, 39-45.

MANDELBAUM J., PLACHOT M., 1979. Infécondabilité de l'ovocyte de Hamster ayant fait sa maturation in vitro. C. R. Acad. Sci., Paris, 284, sér. D, 953-955.

MARO B., JOHNSON M. H., WEBB M., FLACH G., 1986. Mechanism of polar body formation in the mouse oocyte: an interaction between the chromosomes, the cytoskeleton and the plasma membrane. J. Embryol. exp. Morphol., 92, 11-32.

MAUL G. G., SCHATTEN G., 1986. Nuclear lamins during gametogenesis, fertilization and early development. In Nucleocytoplasmic transport, 123-134. PETER R., TREDELENBURG M. eds, Springer-Verlag, Berlin.

MÉNEZO Y., GÉRARD M., THIBAULT C., 1976. Culture du follicule de de Graaf de bovin dans un système à courant liquide et gazeux continu. C. R. Acad. Sci., D, 283, 1309-1311.

MOOR R. M., CROSBY I. M., 1986. Protein requirements for germinal vesicle breakdown in ovine oocytes. J. Embryol. exp. Morphol., 94, 207-220.

MOOR R. M., HESLOP J. P., 1981. Cyclic AMP in mammalian follicle cells and oocytes during maturation. J. exp. Zool., 216, 205-209.

MOOR R. M., OSBORN J. C., 1983. Somatic control of protein synthesis in mammalian oocytes during maturation. In Mol. Biol. Egg Matur., Ciba Foundation, Symp. 98, $178-196$.

MOOR R. M., SMITH M. W., DAWSON R. M. C., 1980. Measurement of intercellular coupling between oocytes and cumulus cells using intracellular markers. Exp. Cell Res., 126, 15-29.

MOOR R. M., TROUNSON A. O., 1977. Hormonal and follicular factors affecting maturation of sheep oocytes in vitro and their subsequent developmental capacity. J. Reprod. Fertil., 49, 101-109.

MOORE G. P. M., LINTERN-MOORE S., 1978. Transcription of the mouse oocyte genome. Biol. Reprod., 17, 865-870.

MORI T., IRAHARA M., SAITO H., OHNO Y., HOSOI E., 1985. Inhibitory action of somatostatin on meiotic maturation of cultured porcine follicular ova. Acta endocr., 110, 408-412.

MORI T., MORIMOTO N., KHODA H., NISHIMURA T., KEMBEGAWA A., 1983. Meiosis inhibiting effect in vivo of antiserum to progesterone on follicular ova in immature rats treated with gonadotropins. Endocr. japon., 30, 593-599.

MORI T., SUZUKI A., FUJITA Y., NISHIMURA T., OHASHI K., KEMBEGAWA A., 1979. Meiosis facilitating effects in vivo of antiserum to estrone on follicular oocytes in immature rats treated with gonadotropins. Biol. Reprod., 20, 681-688.

MORICARD R., MORICARD F., 1975. Espace périvitellin et réactions microvillositaires au cours de l'achèvement de la méiose et de la fécondation chez les Mammifères; orientation de recherches humaines. In THIBAULT C., La fécondation, 37-48. Coll. Soc. nat. Etude Fertil. Steril., Masson, Paris.

MOTLIK J., CROZET N., FULKA J., 1984. Meiotic competence in vitro of pig oocytes isolated from early antral follicles. J. Reprod. Fertil., 72, 323-328.

MOTLIK J., FULKA J., 1974a. Fertilization of pig follicular oocytes cultivated in vitro. J. Reprod. Fertil., 36, 235-237.

MOTLIK J., FULKA J., 1974b. Fertilization and development in vivo of rabbit oocytes cultivated in vitro. J. Reprod. Fertil., 40, 183-186.

MOTLIK J., FULKA J., 1976. Breakdown of germinal vesicle in pig oocytes in vivo and in vitro. J. exp. Zool., 198, 155-162.

MOTLIK J., FULKA J., 1982. Fertilization and developmental capacity of mammalian oocytes cultured in vitro. Embryo transfer in mammals. MÉRIEUX C., BONNEAU M., Eds, Annecy, 142. 
MOTLIK J., FULKA J., 1986. Factors affecting meiotic competence in pig oocytes. Theriogenology, 25, 87-96.

MOTLIK J., FULKA J., FLÉCHON J. E., 1986. Changes in intercellular coupling between pig oocytes and cumulus cells during maturation in vivo and in vitro. J. Reprod. Fertil., 76, 31-37.

MULNER O., OZON R., 1981. The role of follicular envelopes in the initiation of xenopus oocyte maturation. Gen. comp. Endocrin., 44, 335-343.

OKADA A., YANAGIMACHI R., YANAGIMACHI H., 1986. Development of cortical granules free area of cortex and the perivitellin space in the hamster oocyte during maturation and following ovulation. J. Submicrosc. Cytol., 18, 233-247.

OLSIEWSKI P. J., BEERS W. H., 1983. cAMP synthesis in the rat oocyte. Develop. Biol., 100, 287-293.

OSBORN J. C., MOOR R. M., 1982. Cell interaction and actin synthesis in mammalian oocytes. J. exp. Zool., 220, 125-129.

OSBORN J. C., MOOR R. M., 1983. The role of the steroid signals in the maturation of mammalian oocytes. J. Ster. Bioch., 19, 133-137.

OSBORN J. C., MOOR R. M., CROSBY I. M., 1986. Effect of alterations in follicular steroidogenesis on the nuclear and cytoplasmic maturation of ovine oocytes. J. Embryol. exp. Morphol., 98, 187-208.

OVERSTREET J. W., CROSS N. L., MORALES P., HANSON F. W., 1987. Biology of human spermzona pellucida interaction. Proceed. Vth world Congr. on In vitro Fertilization and embryo Transfer, Norfolk, Virginia, USA, April 1987 (in press).

PIKO L., CLEGG K. G., 1982. Quantitative changes in total RNA, total poly A and ribosomes in early mouse embryos. Dev. Biol., 89, 362-378.

PLACHOT M., MANDELBAUM J., 1978. Comparative study of extra- and intrafollicular hamster oocyte maturation. Ann. Biol. anim. Bioch. Biophys., 18, 1237-1246.

QUIRKE J. F., GORDON I., 1971. Culture and Fertilization of sheep oocytes. I. Effect of culture medium on resumption of meiosis. J. agric. Sci., 76, 369-372.

RACOWSKI C., 1984. Effect of forskolin on the spontaneous maturation and cyclic AMP content of rat oocyte-cumulus complexes. J. Reprod. Fertil., 72, 107-116.

RACOWSKY C., 1985a. Effect of forskolin on the spontaneous maturation and cyclic AMP content of hamster oocyte-cumulus complexes. J. exp. Zool., 234, 87-96.

RACOWSKY C., 1985b. Effect of forskolin on meiotic arrest and stimulation of cumulus expansion, progesterone and cyclic AMP production by pig cumulus-oocyte complexes. $J$. Reprod. Fertil., 74, 9-21.

RACOWSKY C., SATTERLIE R. A., 1985. Metabolic, fluorescent dye and electrical coupling between hamster oocytes and cumulus cells during meiotic maturation in vivo and in vitro. Develop. Biol., 108, 191-202.

RACOWSKY C., MCGAUGHEY R. W., 1982. Further studies on the follicular fluid and membrane granulosa cells on the spontaneous maturation of pig oocytes. J. Reprod. Fertil., 66, 505-512.

RICE C., McGAUGHEY R. W., 1981. Effect of testosterone and dibutyryl cAMP on the spontaneous maturation of pig oocytes. J. Reprod. Fertil., 62, 245-246.

RICHTER J. D., McGAUGHEY R. W., 1981. Patterns of polypeptide synthesis in mouse oocytes during germinal vesicle breakdown and during maintenance of the germinal vesicle stage by dibutyryl CAMP. Develop. Biol., 83, 188-192.

RIME H., JESSUS C., OZON R., 1987a. Distribution of microtubules during the first meiotic cell division in the mouse oocyte : effect of taxol. Gamete Res., (in press).

RIME H., JESSUS C., OZON R., 1987b. Estramustine phosphate inhibits germinal vesicle breakdown and induces depolymerization of microtubules in mouse oocytes. Develop. Biol. (in press).

SALUSTRI A., SIRACUSA G., 1983. Metabolic coupling, cumulus expansion and meiotic resumption in mouse cumuli oophori cultured in vitro in the presence of FSH or dbcAMP, or stimulated in vivo by hCG. J. Reprod. Fertil., 68, 335-341.

SATO E., KOIDE S. S., 1984. Forskolin and mouse oocyte maturation in vitro. J. exp. Zool., 230, 125-129.

SATO E., ISHIBASHI I., 1977. Inhibition of compensatory ovarian hypertrophy in the mouse by the administration of the non-dialyzable fraction of bovine follicular fluid. Jap. J. Zootech., 48, 742-783. 
SATO E., UENO H., KOIDE S. S., 1986. Mouse oocyte maturation modulated by a granulosa cell factor and by heparin and heparan sulfate. Gamete Res., 13, 115-124.

SCHATTEN G., SIMERLY C., SCHATTEN H., 1985a. Microtubule configuration during fertilization, mitosis and early development in the mouse and the requirement for egg microtubule-mediated motility during mammalian fertilization. Proc. nat. Acad. Sci, 82, 41524156.

SCHATTEN G., MAUL G. G., SCHATTEN H., CHALY N., SIMERLY C., BALCZON R., BROWN D. L., 1985b. Nuclear lamins and peripheral nuclear antigens during fertilization and embryogenesis in mice and sea urchins. Proc. nat. Acad. Sci. NY, 82, 4727-4731.

SCHROEDER A. C., EPPIG J. J., 1984. The developmental capacity of mouse ocytes that mature spontaneously in vitro is normal. Develop. Biol., 102, 493-498.

SCHULTZ R. M., MONTGOMERY R. R., BELANOFF J., 1983a. Regulation of mouse oocyte maturation. Implication of a decrease in oocyte CAMP and protein dephosphorylation in commitment to resume meiosis. Develop. Biol., 97, 264-273.

SCHULTZ R. M., MONTGOMERY R. R., WARD-BAILEY P. F., EPPIG J. J., 1983b. Regulation of oocyte maturation in the mouse : possible role of intercellular communication, CAMP and testosterone. Develop. Biol., 95, 294-304.

SMITH D. M., TYLER J. P. P., ERICKSON G. F., 1978. Effects of medium composition and progesterone on maturation in vitro of rabbit oocytes from graffian follicles of different sizes. $J$. Reprod. Fertil., 54, 393-400.

SOUPART P., 1975. In vitro maturation and fertilization of human oocyte. In La Fécondation, Coll. Soc. nat. Etude Fertil. Steril., 1-12, THIBAULT C., Masson, Paris.

SREENAN J., 1970. In vitro maturation and attempted fertilization of cattle follicular oocytes. $J$. agric. Sci, 75, 393-396.

STAIGMILLER R. B., MOOR R. M., 1984. Effects of follicle cells on the maturation and developmental competence of ovine oocytes matured outside the follicle. Gamete Res., 9, 221-229.

SUNKARA P. S., WRIGHT D. A., ADHLAKA R. C., SAHASRABUDDHE C. G., RAO P. N., 1982. Characterisation of chromosome condensation factors of mammalian cells. In RAO P. N., JOHNSON R. T., SPERELING K., Premature chromosome condensation. Acad. Press, New York.

SUZUKI S., ENDO Y., MIURA R., IIZUKA R., 1984. Biological effects of trilostane in vitro on oocyte maturation and fertilization in the hamster. Experientia, 40, 1214-1217.

SZÖLLÖSI D., 1971. Nucleoli and ribonucleoprotein particles in the primplantation conceptus of the rat and mouse. In BLANDAU R. J., The biology of the blastocyst, 95-113. Univ. Chicago Press, Chicago.

SZÖLLÖSI D., 1972. Changes of some organelles during oogenesis in mammals, 47-64. In BIGGERS J. D., SCHUETZ A. W., Oogenesis, Univ. Park Press, Baltimore.

SZÖLLÖSI D., 1975. Ultrastructural aspects of oocyte maturation and fertilization in mammals. In THIBAULT C., La fécondation. Coll. Soc. nat. Etude Fertil. Steril., 13-35, Masson, Paris.

SZÖLLÖSI D., 1978. On the role of gap junctions found between follicle cells and oocyte in the mammalian ovarian follicle. Res. Reprod., 10, No 2.

SZÖLLÖSI D., CALARCO P. G., DONAHUE R. P., 1972a. The nuclear envelope : its break-down and fate in mammalian oogonia and oocytes. Anat. Rec., 174, 325-340.

SZÖLLÖSI D., CALARCO P. G., DONAHUE R. P., 1972b. Absence of centrioles in the first and second meiotic spindles of mouse oocytes. J. Cell Sci., 11, 521-541.

SZÖLLÖSI D., GÉRARD M., 1983. Cytoplasmic changes in mammalian oocytes during preovulatory period, 35-55. In BEIER H. M., LINDNER H. R., Fertilization of the human egg in vitro. Springer Verlag, Berlin.

SZÖLLÖSI D., GÉRARD M., MÉNÉZO Y., THIBAULT C., 1978. Permeability of ovarian follicle ; corona cell-oocyte relationship in mammals. Ann. Biol. anim. Bioch. Biophys., 18, 511-521.

SZÖLLÖSI D., HUNTER R. H. F., 1973. Ultrastructural aspects of fertilization in the domestic pig : sperm penetration and pronucleus formation. J. Anat., 116, 181-206.

TAKAHASHI M., KOIDE S. S., DONAHOE P. K., 1986. Müllerian inhibiting substance as oocyte meiosis inhibitor. Mol. cell. Endocr., 47, 225-234. 
TESARIK J., KOPECNY V., DVORAK M., PILKA L., KURILO L. F., 1984 . Human non ovulatorycumulus oocyte complexes : ultrastructure, macromolecular synthesis, and developmental potential. Gamete Res., 9, 153-165.

THIBAULT C., 1977. Are follicular maturation and oocyte maturation independent processes? J. Reprod. Fertil., 51, 1-15.

THIBAULT C., GÉRARD M., 1970. Facteur cytoplasmique nécessaire à la formation du pronucleus mâle dans l'ovocyte de lapine. C. R. Acad. Sci., Paris, 270, 2025-2027.

THIBAULT C., GÉRARD M., 1973. Cytoplasmic and nuclear maturation of rabbit oocytes in vitro. Ann. Biol. anim. Bioch. Biophys., 13, Suppl. 145-155.

THIBAULT C., GÉRARD M., MÉNÉZO Y., 1975a. Preovulatory and ovulatory mechanisms in oocyte maturation. J. Reprod. Fertil., 45, 605-610.

THIBAULT C., GÉRARD M., MÉNÉZO Y., 1975b. Acquisition par l'ovocyte de lapine et de veau du facteur de décondensation du noyau du spermatozoide fécondant (MPGF). Ann. Biol. anim. Bioch. Biophys., 15, 705-714.

THIBAULT C., GÉRARD M., MÉNÉZO Y., 1976. Nuclear and cytoplasmic aspects of mammalian oocyte maturation in vitro in relation to follicle size and fertilization, 233-240. In HUBINONT P. O., Progress in reproductive biology, 1, Karger, Bâle.

TROUNSON A. O., WILLADSEN S. M., ROWSON L. E. A., 1977. Fertilization and developmental capability of bovine follicular oocytes matured in vivo and in vitro and transferred in the oviducts of rabbits and cows. J. Reprod. Fertil., 51, 321-327.

TSAFRIRI A., 1987. Local non-steroidal regulators of ovarian function. In GREENWALD G. S., The physiology of reproduction, II A, The fema/e reproductive system. Raven Press. (In Press).

TSAFRIRI A., CHANNING C. P., 1975. An inhibitory influence of granulosa cells and follicular fluid upon porcine meiosis in vitro. Endocrinology, 96. 922-927.

TSAFRIRI A., POMERANTZ S. H., 1986. Oocyte maturation inhibitor. Clin. Endocr. Metabol., 15, 157-170.

URNER F., HERRMANN W. L., BAULIEU E. E., SCHORDERET-SLATKINE S., 1983. Inhibition of denuded mouse oocyte meiotic maturation by forskolin, an activator of adenylate cyclase. Endocrinology, 113, 1170-1172.

VAN BLERKOM J., BELL H., 1986. Regulation of development in the fully grown mouse oocyte : chromosome-mediated temporal and spatial differenciation of the cytoplasm and the plasma membrane. J. Embryol. exp. Morph., 93, 213-238.

VAN BLERKOM J., McGAUGHEY R. W., 1978. Molecular differenciation of the rabbit ovum. 1. During oocyte maturation in vivo and in vitro. Develop. Biol., 63, 139-150.

VAN BLERKOM J., RUNNER M. N., 1984. Mitochondria reorganization during resumption of arrested meiosis in the mouse oocyte. Amer. J. Anat., 171, 335-355.

VILAIN J. P., MOREAU M., GUERRIER P., 1980. Uncoupling of oocyte-follicle cells triggers reinitiation of meiosis in amphibian oocytes. Develop. Growth Different., 22, 687-691.

VIVARELLI E., CONTI M., DE FELICI M., SIRACUSA G., 1983. Meiotic resumption and intracellular cAMP levels in mouse oocytes treated with compounds which act on cAMP metabolism. Cell Diff., 12, 271-276.

WARNES G. M., MOOR R. M., JOHNSON M. H., 1977. Changes in protein synthesis during maturation of sheep oocytes in vivo and in vitro. J. Reprod. Fertil., 49, 331-335.

WASSARMAN P. M., 1987. The biology and chemistry of fertilization. Science, 235, 553-559.

WASSARMAN P. M., JOSEFOWICZ W. J., 1978. Oocyte development in the mouse. An ultrastructural comparison of oocytes isolated at various stages of growth and meiotic competence. J. Morphol., 156, 209-236.

WEBB M., HOWLETT S. K., MARO B., 1986. Parthenogenesis and cytoskeletal organization in ageing mouse egges. J. Embryol. exp. Morphol., 95, 131-145. 